\title{
A New Reagent System for Attaining High Regio- and Stereoselectivities in Allylic Displacement of 4-Cyclopentene-1,3- diol Monoacetate with Aryl- and Alkenylmagnesium Bromides
}

Yuichi Kobayashi,* Kenya Nakata, and Takayuki Ainai Department of Biomolecular Engineering, Tokyo Institute of Technology B-52, 4259 Nagatsuta-cho, Midori-ku, Yokohama 226-8501, Japan ykobayas@bio.titech.ac.jp

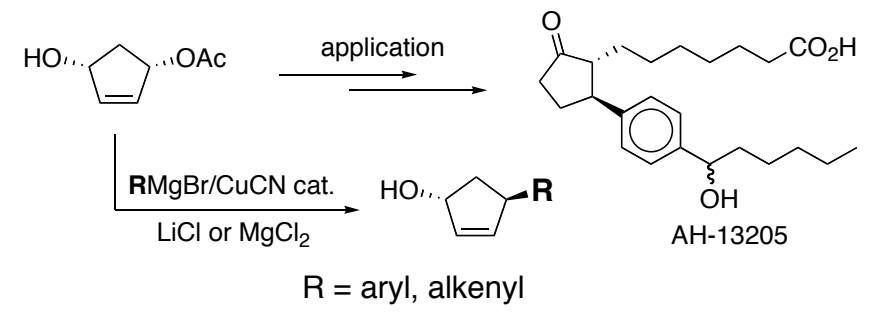

(1) General Procedure for $\mathrm{CuCN}$-Catalyzed Reaction with $\mathrm{ArMgBr} \quad \mathrm{S} 2$

(2) Synthesis of AH-13205 (9) from monoacetate $1 \quad$ S3-S7

(3) Spectra of the following compounds and pages S8-S28

2d, ${ }^{1} \mathrm{H}$ NMR (S8)

2f, ${ }^{1} \mathrm{H}$ NMR (S10)

15, ${ }^{1} \mathrm{H}$ NMR (S12)

23, ${ }^{1} \mathrm{H}$ NMR (S14)

16, ${ }^{1} \mathrm{H}$ NMR (S15)

19, ${ }^{1} \mathrm{H}$ NMR (S17)

20, ${ }^{1} \mathrm{H}$ NMR (S19) 2d, ${ }^{13} \mathrm{C}$ NMR (S9)

2f, ${ }^{13} \mathrm{C}$ NMR (S11)

15, ${ }^{13} \mathrm{C}$ NMR (S13)

16, ${ }^{13} \mathrm{C}$ NMR (S16)

19, ${ }^{13} \mathrm{C}$ NMR (S18)

20, ${ }^{13} \mathrm{C}$ NMR (S20)

keto aldehyde from 20, ${ }^{1} \mathrm{H}$ NMR (S21)

keto aldehyde from 20, ${ }^{13} \mathrm{C}$ NMR (S22)

21, ${ }^{1} \mathrm{H}$ NMR (S23)

21, ${ }^{13} \mathrm{C}$ NMR (S24)

24, ${ }^{1} \mathrm{H}$ NMR (S25)

24, ${ }^{13} \mathrm{C}$ NMR (S26)

AH-13205 (9), ${ }^{1} \mathrm{H}$ NMR (S27)

AH-13205 (9), ${ }^{13} \mathrm{C}$ NMR (S28) 


\section{General Procedure for CuCN-Catalyzed Reaction with ArMgBr.}

(1) With LiCl: A $25 \mathrm{~mL}$ two-necked flask was charged with $\mathrm{LiCl}(50.9 \mathrm{mg}, 1.20$ mmol) and heated up in vacuo to remove water. After being cooled to room temperature, $\mathrm{CuCN}(8.1 \mathrm{mg}, 0.09 \mathrm{mmol})$ and THF $(1 \mathrm{~mL})$ were added in order. To the mixture cooled to $0{ }^{\circ} \mathrm{C}$ were added $\mathrm{PhMgBr}(1.36 \mathrm{~mL}, 0.66 \mathrm{M}$ in THF, $0.90 \mathrm{mmol})$ and, after $15 \mathrm{~min}, 4-$ cyclopentene-1,3-diol monoacetate (1) $(42.6 \mathrm{mg}, 0.30 \mathrm{mmol})$ in THF (1 mL). The mixture was stirred for $1 \mathrm{~h}$ at the same temperature and then diluted with saturated $\mathrm{NH}_{4} \mathrm{Cl}$. After extraction with EtOAc four times, the combined extracts were dried over $\mathrm{MgSO}_{4}$ and evaporated under reduced pressure. The residue was purified by silica gel chromatography (hexane/EtOAc $=4: 1)$ to afford 4-phenyl-2-cyclopenten-1-ol (2a) (44.9 $\mathrm{mg}, 94 \%)$.

(2) With $\mathbf{M g C l}_{2}$ : A $25 \mathrm{~mL}$ two-necked flask was charged with $\mathrm{Mg}(29.2 \mathrm{mg}, 1.20$ $\mathrm{mmol})$ and heated up in vacuo. After being cooled to room temperature, THF $(0.5 \mathrm{~mL})$ and 1,2-dichloroethane $(0.28 \mathrm{~mL}, 3.60 \mathrm{mmol})$ were added in order. The mixture was heated for $5 \mathrm{~min}$ and stirred for $20 \mathrm{~min}$. THF $(0.5 \mathrm{~mL})$ was added to the mixture, and the above operation was repeated again to dissolve $\mathrm{Mg}$ completely. The resulting suspension was diluted with THF $(1 \mathrm{~mL})$ to produce a clear solution. To the solution cooled to $0{ }^{\circ} \mathrm{C}$ were added $\mathrm{PhMgBr}(0.92 \mathrm{~mL}, 0.98 \mathrm{M}$ in THF, $0.90 \mathrm{mmol})$ and, after 15 min, monoacetate 1 (42.6 mg, $0.30 \mathrm{mmol})$ in THF ( $1 \mathrm{~mL})$. The mixture was stirred for 1 $h$ at the same temperature and diluted with saturated $\mathrm{NH}_{4} \mathrm{Cl}$. The product was extracted and purified as above to afford $\mathbf{2 a}(35.2 \mathrm{mg}, 73 \%)$.

Products 2a-c and 2e: the spectral data for these products were consistent with those reported previously: Kobayashi, Y.; Murugesh, M. G.; Nakano, M.; Takahisa, E.; Usmani, S. B.; Ainai, T. J. Org. Chem. 2002, 67, 7110-7123.

4-(2-Methoxyphenyl)cyclopenten-1-ol (2d): IR (neat): 3338, 1030, $753 \mathrm{~cm}^{-1} ;{ }^{1} \mathrm{H}$ $\mathrm{NMR}\left(\mathrm{CDCl}_{3}, 300 \mathrm{MHz}\right) \square 1.44(\mathrm{~d}, J=7 \mathrm{~Hz}, 1 \mathrm{H}), 2.02(\mathrm{ddd}, J=14,7,5.5 \mathrm{~Hz}, 1 \mathrm{H})$, 2.29 (ddd, $J=14,8,3 \mathrm{~Hz}, 1 \mathrm{H}), 4.46-4.56(\mathrm{~m}, 1 \mathrm{H}), 4.96-5.06(\mathrm{~m}, 1 \mathrm{H}), 6.00-6.08$ (m, $2 \mathrm{H}), 6.83-6.92(\mathrm{~m}, 2 \mathrm{H}), 7.02(\mathrm{dd}, J=7,2 \mathrm{~Hz}, 1 \mathrm{H}), 7.19(\mathrm{dt}, J=8,2 \mathrm{~Hz}, 1 \mathrm{H}) ;{ }^{13} \mathrm{C}$ $\mathrm{NMR}\left(\mathrm{CDCl}_{3}, 75 \mathrm{MHz}\right) \square$ 42.6, 43.0, 55.4, 77.5, 110.4, 120.6, 126.7, 127.3, 133.2, 134.1, 138.5, 157.1. Anal. Calcd for $\mathrm{C}_{12} \mathrm{H}_{14} \mathrm{O}_{2}$ : C, 75.76; H, 7.42. Found: C, 75.90; H, 7.69 .

4-(3,4-Metylenedioxyphenyl)cyclopenten-1-ol (2f): IR (nujol): 3232, $1094 \mathrm{~cm}^{-1}$; ${ }^{1} \mathrm{H} \mathrm{NMR}\left(\mathrm{CDCl}_{3}, 300 \mathrm{MHz}\right) \square 1.69-1.93$ (br s, $\left.1 \mathrm{H}\right), 2.04$ (ddd, $\left.J=14,7,5.5 \mathrm{~Hz}, 1 \mathrm{H}\right)$, 2.25 (ddd, $J=10,8,3 \mathrm{~Hz}, 1 \mathrm{H}), 4.06$ (dd, $J=8,6 \mathrm{~Hz}, 1 \mathrm{H}), 4.97-5.08$ (m, $1 \mathrm{H}), 5.91$ (s, $2 \mathrm{H}), 5.96-6.02(\mathrm{~m}, 2 \mathrm{H}), 6.56-6.62(\mathrm{~m}, 2 \mathrm{H}), 6.72(\mathrm{~d}, J=8 \mathrm{~Hz}, 1 \mathrm{H}) ;{ }^{13} \mathrm{C} \mathrm{NMR}$ $\left(\mathrm{CDCl}_{3}, 75 \mathrm{MHz}\right) \square 44.2,49.7,77.4,100.9,107.4,108.2,120.0,134.0,138.8,139.2$, 
146.0, 147.8. Anal. Calcd for $\mathrm{C}_{12} \mathrm{H}_{12} \mathrm{O}_{3}$ : C, 70.57; H, 5.92. Found: C, 70.52; H, 6.19.

4-(4-(1-(t-Butyldimethylsilyloxy)hexyl)phenyl)-2-cyclopenten-1-ol (15). To a 50 $\mathrm{mL}$ two-necked flask charged with $\mathrm{LiCl}(298 \mathrm{mg}, 7.03 \mathrm{mmol})$ were added CuCN (47 $\mathrm{mg}, 0.52 \mathrm{mmol})$ and THF $(6 \mathrm{~mL})$. The mixture was cooled to $0{ }^{\circ} \mathrm{C}$ and Grignard reagent 14 (9.78 mL, $0.54 \mathrm{M}$ in THF, $5.28 \mathrm{mmol}$ ) was added slowly. After $15 \mathrm{~min},(1 R, 3 S)$ enantiomer of 1 ( $250 \mathrm{mg}, 1.76 \mathrm{mmol}$ ) was added to start the reaction, which was carried out at $0{ }^{\circ} \mathrm{C}$ for $1 \mathrm{~h}$. Saturated $\mathrm{NH}_{4} \mathrm{Cl}$ was added and the product was extracted with EtOAc four times. The combined extracts were dried over $\mathrm{MgSO}_{4}$ and evaporated under reduced pressure. The residue was purified by silica gel chromatography (hexane/EtOAc = 4:1) to afford $15(649 \mathrm{mg}, 98 \%)$ : [ $]^{26}{ }_{\mathrm{D}}=-147.5\left(c 1.08, \mathrm{CHCl}_{3}\right)$; IR (neat): $3324,1085,836 \mathrm{~cm}^{-1}$; ${ }^{1} \mathrm{H} \mathrm{NMR}\left(\mathrm{CDCl}_{3}, 300 \mathrm{MHz}\right) \square-0.16(\mathrm{~s}, 3 \mathrm{H}), 0.01$ (s, 3 $\mathrm{H}), 0.85(\mathrm{t}, J=7 \mathrm{~Hz}, 3 \mathrm{H}), 0.87(\mathrm{~s}, 9 \mathrm{H}), 1.25-1.44(\mathrm{~m}, 6 \mathrm{H}), 1.44-1.74(\mathrm{~m}, 3 \mathrm{H}), 2.10$ (dddd, $J=14,7,6,1 \mathrm{~Hz}, 1 \mathrm{H}), 2.28$ (ddd, $J=14,8,3 \mathrm{~Hz}, 1 \mathrm{H}), 4.09-4.17(\mathrm{~m}, 1 \mathrm{H})$, $4.58(\mathrm{dd}, J=8,5 \mathrm{~Hz}, 1 \mathrm{H}), 5.05(\mathrm{tq}, J=7,2 \mathrm{~Hz}, 1 \mathrm{H}), 6.02(\mathrm{dt}, J=5,2 \mathrm{~Hz}, 1 \mathrm{H}), 6.06$ $(\mathrm{dd}, J=5,2 \mathrm{~Hz}, 1 \mathrm{H}), 7.04(\mathrm{~d}, J=8 \mathrm{~Hz}, 2 \mathrm{H}), 7.19(\mathrm{~d}, J=8 \mathrm{~Hz}, 2 \mathrm{H}) ;{ }^{13} \mathrm{C} \mathrm{NMR}$ $\left(\mathrm{CDCl}_{3}, 75 \mathrm{MHz}\right) \square-4.9,-4.5,14.1,18.3,22.7,25.4,25.9,31.8,41.1,44.1$ and 44.2, 49.6, 74.9, 77.5, 126.0, 126.6, 133.8, 139.4, 143.1, 144.1. Anal. Calcd for $\mathrm{C}_{23} \mathrm{H}_{38} \mathrm{O}_{2} \mathrm{Si}: \mathrm{C}$, 73.74; H, 10.22. Found: C, 73.47; H, 10.47.

2-(4-(1-(t-Butyldimethylsilyloxy)hexyl)phenyl)-3-cyclopenten-1-ol (23). To an ice-cold suspension of $\mathrm{CuCN}(8.1 \mathrm{mg}, 0.19 \mathrm{mmol})$ in $\mathrm{THF}(0.5 \mathrm{~mL})$ was added Grignard reagent $14(1.67 \mathrm{~mL}, 0.54 \mathrm{M}$ in THF, $0.90 \mathrm{mmol})$ slowly. After $20 \mathrm{~min}$, a solution of monoacetate 1 (43 mg, $0.30 \mathrm{mmol})$ in THF $(1 \mathrm{~mL})$ was added. The reaction mixture was stirred at $0{ }^{\circ} \mathrm{C}$ for $1 \mathrm{~h}$ and diluted with saturated $\mathrm{NH}_{4} \mathrm{Cl}$. After extraction with EtOAc four times, the combined extracts were dried over $\mathrm{MgSO}_{4}$ and evaporated under reduced pressure. The residue was a mixture of $\mathbf{1 5}$ and 23 in a ratio of $80: 20$ by ${ }^{1} \mathrm{H}$ NMR spectroscopy, and was purified by silica gel chromatography (hexane/EtOAc $=$ 9:1 to 4:1). Minor isomer 23: ${ }^{1} \mathrm{H}$ NMR $\left(\mathrm{CDCl}_{3}, 300 \mathrm{MHz}\right) \square-0.15(\mathrm{~s}, 3 \mathrm{H}), 0.01$ (s, 3 H), $0.86(\mathrm{t}, J=7 \mathrm{~Hz}, 3 \mathrm{H}), 0.88$ (s, $9 \mathrm{H}), 1.24-1.42(\mathrm{~m}, 6 \mathrm{H}), 1.50-1.74(\mathrm{~m}, 2 \mathrm{H}), 1.83$ (br s, $1 \mathrm{H}$ ), 2.37 (ddq, $J=17,4,2 \mathrm{~Hz}, 1 \mathrm{H}$ ), 2.81 (ddq, $J=17,7,2 \mathrm{~Hz}, 1 \mathrm{H}$ ), 3.72-3.78 $(\mathrm{m}, 1 \mathrm{H}), 4.28(\mathrm{br} \mathrm{s}, 1 \mathrm{H}), 4.60(\mathrm{dd}, J=7,5 \mathrm{~Hz}, 1 \mathrm{H}), 5.78(\mathrm{dq}, J=6,2 \mathrm{~Hz}, 1 \mathrm{H}), 5.89$ $(\mathrm{dq}, J=6,2 \mathrm{~Hz}, 1 \mathrm{H}), 7.10(\mathrm{~d}, J=8 \mathrm{~Hz}, 2 \mathrm{H}), 7.21(\mathrm{~d}, J=8 \mathrm{~Hz}, 2 \mathrm{H})$.

Acetate 16 from 4-(4-(1-(t-Butyldimethylsilyloxy)hexyl)phenyl)-2-cyclopenten1-ol. A solution of alcohol $15(649 \mathrm{mg}, 1.73 \mathrm{mmol})$ in pyridine $(0.70 \mathrm{~mL}, 8.65 \mathrm{mmol})$ 
and acetic anhydride $(0.49 \mathrm{~mL}, 5.2 \mathrm{mmol})$ was stirred at room temperature for $1 \mathrm{~h}$. Saturated $\mathrm{NaHCO}_{3}$ was added and the resulting mixture was extracted with EtOAc four times. The combined extracts were dried over $\mathrm{MgSO}_{4}$ and concentrated in vacuo to leave an oil, which was purified by silica gel chromatography (hexane/EtOAc $=4: 1$ ) to give acetate 16 (669 mg, 93\%): [ $\square]_{\mathrm{D}}^{26}=-179.3\left(c 1.08, \mathrm{CHCl}_{3}\right)$; IR (neat) 1738, 1085, $836 \mathrm{~cm}^{-1} ;{ }^{1} \mathrm{H}$ NMR $\left(\mathrm{CDCl}_{3}, 300 \mathrm{MHz}\right) \square-0.16(\mathrm{~s}, 3 \mathrm{H}), 0.00(\mathrm{~s}, 3 \mathrm{H}), 0.85$ (t, $J=7 \mathrm{~Hz}$, $3 \mathrm{H}), 0.87$ (s, 9 H), 1.24-1.40 (m, $6 \mathrm{H}), 1.49-1.73$ (m, 2 H), 2.05 (s, $3 \mathrm{H}), 2.13$ (ddd, $J=$ 14, 7, $6 \mathrm{~Hz}, 1 \mathrm{H}), 2.38$ (ddd, $J=14,8,3 \mathrm{~Hz}, 1 \mathrm{H}), 4.10$ (tt, $J=8,2 \mathrm{~Hz}, 1 \mathrm{H}), 4.59$ (dd, $J$ $=7,5 \mathrm{~Hz}, 1 \mathrm{H}), 5.84(\mathrm{dq}, J=7,2 \mathrm{~Hz}, 1 \mathrm{H}), 6.00(\mathrm{dt}, J=5.5,2 \mathrm{~Hz}, 1 \mathrm{H}), 6.15(\mathrm{dd}, J=$ 5.5, $2 \mathrm{~Hz}, 1 \mathrm{H}), 7.04(\mathrm{~d}, J=8 \mathrm{~Hz}, 2 \mathrm{H}), 7.20(\mathrm{~d}, J=8 \mathrm{~Hz}, 2 \mathrm{H}) ;{ }^{13} \mathrm{C} \mathrm{NMR}\left(\mathrm{CDCl}_{3}, 75\right.$ $\mathrm{MHz}) \square-4.9,-4.5,14.1,18.3,21.4,22.7,25.4,25.9,31.8,40.55$ and 40.59, 41.1, 49.7, 74.9, 80.5, 126.1, 126.7, 130.0, 141.8, 142.6, 144.4, 171.1. Anal. Calcd for $\mathrm{C}_{25} \mathrm{H}_{40} \mathrm{O}_{3} \mathrm{Si}$ : C, 72.06; H, 9.68. Found: C, 72.01; H, 9.75.

\section{3-(4-(1-(t-Butyldimethylsilyloxy)hexyl)phenyl)-2-(7-(4-}

(methoxy)benzyloxy)heptyl)cyclopentan-1-ol (19). To an ice-cold slurry of CuCN (33 $\mathrm{mg}, 0.37 \mathrm{mmol})$ in $\mathrm{Et}_{2} \mathrm{O}(6 \mathrm{~mL})$ was added $\mathrm{PMBO}\left(\mathrm{CH}_{2}\right)_{7} \mathrm{MgBr}(6.20 \mathrm{~mL}, 0.30 \mathrm{M}$ in $\left.\mathrm{Et}_{2} \mathrm{O}, 1.86 \mathrm{mmol}\right)$ slowly. After $20 \mathrm{~min}$, a solution of acetate $16(515 \mathrm{mg}, 1.24 \mathrm{mmol})$ in $\mathrm{Et}_{2} \mathrm{O}(1 \mathrm{~mL})$ was added dropwise. The mixture was stirred at $0{ }^{\circ} \mathrm{C}$ for $1 \mathrm{~h}$, and diluted with saturated $\mathrm{NH}_{4} \mathrm{Cl}$ with vigorous stirring. The product was extracted with EtOAc three times. The combined layers were dried over $\mathrm{MgSO}_{4}$ and evaporated under reduced pressure to give an oil, which was passed through a short silica gel column (hexane/EtOAc = 20:1) to afford semi-purified olefin 17.

To an ice-cold mixture of the above olefin 17 and $\mathrm{NaHCO}_{3}(417 \mathrm{mg}, 4.97 \mathrm{mmol}$ ) in $\mathrm{CH}_{2} \mathrm{Cl}_{2}(20 \mathrm{~mL})$ was added $m$-CPBA $(556 \mathrm{mg}, 77 \%$ purity, $2.48 \mathrm{mmol})$ in portions. The mixture was stirred at room temperature for $10 \mathrm{~h}$, and excess reagent was quenched by addition of $\mathrm{Me}_{2} \mathrm{~S}(0.15 \mathrm{~mL}, 2.0 \mathrm{mmol})$ with vigorous stirring for $10 \mathrm{~min}$. The mixture was diluted with saturated $\mathrm{NaHCO}_{3}$ and $\mathrm{CH}_{2} \mathrm{Cl}_{2}$. The layers were separated, and the aqueous layer was extracted with EtOAc four times. The combined organic layers were dried over $\mathrm{MgSO}_{4}$ and concentrated under reduced pressure to give an oil, which was passed through a short column of silica gel (hexane/EtOAc $=20: 1$ to 9:1) to furnish epoxide 18.

To a solution of the above epoxide 18 in THF $(12 \mathrm{~mL})$ was added $\mathrm{LiB}\left(\mathrm{H}_{)} \mathrm{Et}_{3}(7.08\right.$ $\mathrm{mL}, 1.05 \mathrm{M}$ in THF, $7.44 \mathrm{mmol}$ ) slowly. After being stirred at room temperature for 12 $\mathrm{h}$, the solution was cooled to $0{ }^{\circ} \mathrm{C}$ and diluted with saturated $\mathrm{NH}_{4} \mathrm{Cl}$ and EtOAc with vigorous stirring. The layers were separated and the aqueous layers was extracted with 
EtOAc three times. The combined extracts were dried over $\mathrm{MgSO}_{4}$ and concentrated in vacuo. The residue was purified by silica gel chromatography (hexane/EtOAc $=9: 1$ to 4:1) to afford alcohol 19 (278 mg, 37\% for 3 steps): [ []$_{D}^{24}=-4.6\left(c 1.14, \mathrm{CHCl}_{3}\right)$; IR (neat) 3385, 1085, $836 \mathrm{~cm}^{-1}$; ${ }^{1} \mathrm{H} \mathrm{NMR}\left(\mathrm{CDCl}_{3}, 300 \mathrm{MHz}\right) \square-0.18(\mathrm{~s}, 3 \mathrm{H}), 0.00$ (s, 3 $\mathrm{H}), 0.85(\mathrm{t}, J=6 \mathrm{~Hz}, 3 \mathrm{H}), 0.86(\mathrm{~s}, 9 \mathrm{H}), 1.03-1.43(\mathrm{~m}, 16 \mathrm{H}), 1.46-1.74(\mathrm{~m}, 6 \mathrm{H})$, 1.81-1.97 (m, 2 H), 2.06-2.18 (m, 1 H), 2.21-2.32 (m, $1 \mathrm{H}), 3.39$ (t, $J=7 \mathrm{~Hz}, 2 \mathrm{H})$, $3.51(\mathrm{q}, J=8 \mathrm{~Hz}, 1 \mathrm{H}), 3.80(\mathrm{~s}, 3 \mathrm{H}), 4.11-4.18(\mathrm{~m}, 1 \mathrm{H}), 4.41(\mathrm{~s}, 2 \mathrm{H}), 4.58(\mathrm{dd}, J=8$, $5 \mathrm{~Hz}, 1 \mathrm{H}), 6.87(\mathrm{~d}, J=8 \mathrm{~Hz}, 2 \mathrm{H}), 7.07(\mathrm{~d}, J=8 \mathrm{~Hz}, 2 \mathrm{H}), 7.18(\mathrm{~d}, J=8 \mathrm{~Hz}, 2 \mathrm{H}), 7.25$ $(\mathrm{d}, J=8 \mathrm{~Hz}, 2 \mathrm{H}) ;{ }^{13} \mathrm{C} \mathrm{NMR}\left(\mathrm{CDCl}_{3}, 75 \mathrm{MHz}\right) \square-4.9,-4.5,14.1,18.3,22.7,25.5,25.9$, 26.2, 27.5, 27.8, 28.0, 29.4, 29.75 and 29.79, 31.8, 33.8, 40.9, 45.8 and 45.9, 52.9, 55.3, 70.2, 72.5, 75.1, 78.0, 113.8, 125.7, 128.0, 129.3, 130.8, 141.09 and 141.1, 143.55 and 143.57, 159.1. Anal. Calcd for $\mathrm{C}_{38} \mathrm{H}_{62} \mathrm{O}_{4} \mathrm{Si}$ : C, 74.70; H, 10.23. Found: C, 74.26; H, 10.08 .

\section{3-(4-(1-(t-Butyldimethylsilyloxy)hexyl)phenyl)-2-(7-}

(hydroxy)heptyl)cyclopentan-1-ol (20). To an ice-cold suspension of PMB ether 19 (278 mg, $0.454 \mathrm{mmol})$ in $\mathrm{CH}_{2} \mathrm{Cl}_{2} / \mathrm{H}_{2} \mathrm{O}(1 \mathrm{~mL}, 19: 1)$ was added DDQ (155 mg, 0.681 $\mathrm{mmol}$ ) in portions. The mixture was stirred vigorously for $30 \mathrm{~min}$, and diluted with saturated $\mathrm{NaHCO}_{3}$ and $\mathrm{CH}_{2} \mathrm{Cl}_{2}$. The layers were separated and the aqueous layer was extracted with EtOAc three times. The combined organic layers were dried over $\mathrm{MgSO}_{4}$, and concentrated under reduced pressure. The residue was purified by silica gel

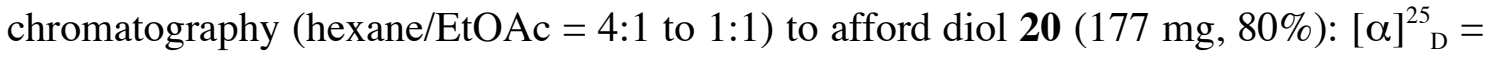
-5.9 (c 0.51, $\left.\mathrm{CHCl}_{3}\right)$; IR (neat) 3336, 1082, $836 \mathrm{~cm}^{-1} ;{ }^{1} \mathrm{H} \mathrm{NMR}\left(\mathrm{CDCl}_{3}, 300 \mathrm{MHz}\right) \square$ $-0.17(\mathrm{~s}, 3 \mathrm{H}), 0.00(\mathrm{~s}, 3 \mathrm{H}), 0.85(\mathrm{t}, J=5 \mathrm{~Hz}, 3 \mathrm{H}), 0.86(\mathrm{~s}, 9 \mathrm{H}), 1.04-1.42(\mathrm{~m}, 17 \mathrm{H})$, 1.45-1.74 (m, 6 H), 1.81-1.99 (m, 2 H), 2.02-2.17 (m, 1 H), 2.21-2.32 (m, 1 H), 3.51 $(\mathrm{q}, J=8 \mathrm{~Hz}, 1 \mathrm{H}), 3.60(\mathrm{t}, J=7 \mathrm{~Hz}, 2 \mathrm{H}), 4.12-4.17(\mathrm{~m}, 1 \mathrm{H}), 4.58(\mathrm{dd}, J=8,5 \mathrm{~Hz}, 1$ $\mathrm{H}), 7.08(\mathrm{~d}, J=8 \mathrm{~Hz}, 2 \mathrm{H}), 7.19(\mathrm{~d}, J=8 \mathrm{~Hz}, 2 \mathrm{H}) ;{ }^{13} \mathrm{C} \mathrm{NMR}\left(\mathrm{CDCl}_{3}, 75 \mathrm{MHz}\right) \square-4.9$, -4.6, 14.1, 18.3, 22.6, 25.4, 25.7, 25.9, 27.5, 27.7, 27.9, 29.2, 29.7, 31.8, 32.7, 33.7, $40.9,45.80$ and 45.83, 52.8, 62.9, 75.0, 77.9, 125.6, 128.0, 141.1 and 141.2, 143.48 and 143.50. Anal. Calcd for $\mathrm{C}_{30} \mathrm{H}_{54} \mathrm{O}_{3} \mathrm{Si}: \mathrm{C}, 73.41 ; \mathrm{H}, 11.09$. Found: C, 73.26; H, 10.98.

7-(5-(4-(1-(t-Butyldimethylsilyloxy)hexyl)phenyl)-2-oxo-cyclopentyl)heptanal. A mixture of diol 20 (177 mg, $0.361 \mathrm{mmol})$ and PCC (238 mg, $1.10 \mathrm{mmol})$ in $\mathrm{CH}_{2} \mathrm{Cl}_{2}$ (2 $\mathrm{mL}$ ) was stirred vigorously at room temperature for $4 \mathrm{~h}$, and diluted with $\mathrm{Et}_{2} \mathrm{O}$ with vigorous stirring. The resulting mixture was filtered through a pad of Celite with $\mathrm{Et}_{2} \mathrm{O}$. The filtrate was washed with $\mathrm{H}_{2} \mathrm{O}$ twice, dried over $\mathrm{MgSO}_{4}$, and concentrated in vacuo 
to give the corresponding keto aldehyde, which was used for the next reaction without further purification.

The above reaction was repeated and the crude keto aldehyde was purified by silica gel chromatography (hexane/EtOAc $=4: 1):[\square]^{23}{ }_{\mathrm{D}}=+13.9\left(c 1.25, \mathrm{CHCl}_{3}\right)$; IR (neat) 1738, 1085, $836 \mathrm{~cm}^{-1}$; ${ }^{1} \mathrm{H} \mathrm{NMR}\left(\mathrm{CDCl}_{3}, 300 \mathrm{MHz}\right) \square-0.19(\mathrm{~s}, 3 \mathrm{H}),-0.01(\mathrm{~s}, 3 \mathrm{H})$, $0.84(\mathrm{t}, J=6 \mathrm{~Hz}, 3 \mathrm{H}), 0.85(\mathrm{~s}, 9 \mathrm{H}), 0.86-1.74(\mathrm{~m}, 18 \mathrm{H}), 2.11-2.59$ (m, $6 \mathrm{H}), 3.57$ (q, $J=6 \mathrm{~Hz}, 1 \mathrm{H}), 4.58(\mathrm{dd}, J=7,5 \mathrm{~Hz}, 1 \mathrm{H}), 7.00(\mathrm{~d}, J=8 \mathrm{~Hz}, 2 \mathrm{H}), 7.20(\mathrm{~d}, J=8 \mathrm{~Hz}, 2$ $\mathrm{H}), 9.70(\mathrm{t}, J=2 \mathrm{~Hz}, 1 \mathrm{H}) ;{ }^{13} \mathrm{C} \mathrm{NMR}\left(\mathrm{CDCl}_{3}, 75 \mathrm{MHz}\right) \square-4.9,-4.6,14.1,18.3,21.9$, 22.6, 25.3, 25.4, 25.9, 26.49 and 26.55, 27.15 and 27.17, 28.77 and 28.80, 29.22 and $29.23,31.8,36.4,40.9,43.8,45.04$ and 45.06, 53.8, 74.9, 126.1, 127.5, 139.5, 144.4, 202.8, 220.60 and 220.64 .

\section{7-(5-(4-(1-(t-Butyldimethylsilyloxy)hexyl)phenyl)-2-oxo-cyclopentyl)heptanoic}

acid (21). To a solution of the above aldehyde in $t$ - $\mathrm{BuOH}(4.7 \mathrm{~mL})$ were added 2methyl-2-butene $(0.384 \mathrm{~mL}, 3.61 \mathrm{mmol})$, phosphate buffer $(2.3 \mathrm{~mL}, \mathrm{pH} 3.6)$, and a solution of $\mathrm{NaClO}_{2}(62 \mathrm{mg}, 80 \%$ purity, $0.55 \mathrm{mmol})$ in $\mathrm{H}_{2} \mathrm{O}(1.8 \mathrm{~mL})$. The resulting mixture was stirred vigorously at room temperature for $9 \mathrm{~h}$, and excess reagent was quenched by addition of saturated $\mathrm{Na}_{2} \mathrm{SO}_{3}$. After $10 \mathrm{~min}$ of vigorous stirring, the aqueous layer was acidified ( $\mathrm{pH} c a .6)$ with phosphate buffer $(\mathrm{pH} 3.6)$ and the product was extracted with EtOAc four times. The combined layers were dried over $\mathrm{MgSO}_{4}$. After concentration under reduced pressure, the residue was subjected to silica gel chromatography (hexane/EtOAc $=1: 1)$ to give acid $21\left(128 \mathrm{mg}, 70 \%\right.$ from 20): $[\square]^{28}{ }_{\mathrm{D}}=$ +12.7 (c 1.72, $\mathrm{CHCl}_{3}$ ); IR (neat) 3000, 1738, 1711, 1085, $836 \mathrm{~cm}^{-1} ;{ }^{1} \mathrm{H} \mathrm{NMR}\left(\mathrm{CDCl}_{3}\right.$, $300 \mathrm{MHz}) \square-0.18(\mathrm{~s}, 3 \mathrm{H}), 0.00(\mathrm{~s}, 3 \mathrm{H}), 0.85(\mathrm{t}, J=6 \mathrm{~Hz}, 3 \mathrm{H}), 0.86(\mathrm{~s}, 9 \mathrm{H})$, 0.98-1.74 (m, $18 \mathrm{H}), 2.11-2.61(\mathrm{~m}, 7 \mathrm{H}), 3.53-3.62(\mathrm{~m}, 1 \mathrm{H}), 4.58$ (dd, $J=8,5 \mathrm{~Hz}, 1$ $\mathrm{H}), 7.01(\mathrm{~d}, J=8 \mathrm{~Hz}, 2 \mathrm{H}), 7.20(\mathrm{~d}, J=8 \mathrm{~Hz}, 2 \mathrm{H}) ;{ }^{13} \mathrm{C} \mathrm{NMR}\left(\mathrm{CDCl}_{3}, 75 \mathrm{MHz}\right) \square-4.9$, $-4.6,14.1,18.3,22.6,24.6,25.3,25.4,25.9,26.50$ and 26.55, 27.15 and 27.17, 28.69 and $28.71,29.09$ and 29.11, 31.7, 34.0, 36.4, 40.8, 45.05 and 45.07, 53.8, 74.9, 126.1, $127.5,139.5,144.4,180.0,220.76$ and 220.80 .

AH-13205 (9). To a solution of acid 21 (18.2 $\mathrm{mg}, 0.0362 \mathrm{mmol})$ in DMF/NMP (0.385 mL, 10:1) was added $\mathrm{NH}_{4} \mathrm{~F} \cdot \mathrm{HF}$ (20.6 mg, $\left.0.362 \mathrm{mmol}\right)$. The mixture was stirred vigorously at room temperature for $72 \mathrm{~h}$, and acidified to $\mathrm{pH} c a$. 5 with phosphate buffer ( $\mathrm{pH}$ 3.6). The product was extracted with hexane/Et $2 \mathrm{O}(1: 1)$ four times. The combined extracts were dried over $\mathrm{MgSO}_{4}$ and concentrated to leave 22 as an oil, which was a ca. 1:1 mixture of $\mathrm{AH}-13205$ and its epimer at $\mathrm{C}(8)$. 
The mixture was treated with $\mathrm{LiOH} \cdot \mathrm{H}_{2} \mathrm{O}(3.6 \mathrm{mg}, 0.086 \mathrm{mmol})$ in $\mathrm{THF} / \mathrm{MeOH} / \mathrm{H}_{2} \mathrm{O}$ $(0.175 \mathrm{~mL}, 3: 1: 1)$ for $1.5 \mathrm{~h}$ at room temperature. Saturated $\mathrm{NH}_{4} \mathrm{Cl}$ was added, and the aqueous layer was acidified to $\mathrm{pH} c a$. 6 with phosphate buffer ( $\mathrm{pH}$ 3.6). The mixture was extracted with EtOAc four times and the combined layers were dried over $\mathrm{MgSO}_{4}$. After concentration under reduced pressure, the residue was purified by silica gel chromatography $\left(\mathrm{CH}_{2} \mathrm{Cl}_{2} / \mathrm{EtOAc}=1: 2\right)$ to give $\mathrm{AH}-13205(\mathbf{9})(8.04 \mathrm{mg}, 49 \%$ from 21): $[\square]_{\mathrm{D}}^{30}=-26.1$ (c 0.18, $\mathrm{CHCl}_{3}$ ); IR (neat): 3434, 1738, 1717, $832 \mathrm{~cm}^{-1} ;{ }^{1} \mathrm{H} \mathrm{NMR}$ $\left(\mathrm{CDCl}_{3}, 300 \mathrm{MHz}\right) \square 0.87(\mathrm{t}, J=6 \mathrm{~Hz}, 3 \mathrm{H}), 1.0-2.0(\mathrm{~m}, 19 \mathrm{H}), 2.14-2.37(\mathrm{~m}, 5 \mathrm{H})$, 2.45-2.60 (m, $1 \mathrm{H}), 2.96(\mathrm{dt}, J=6,12 \mathrm{~Hz}, 1 \mathrm{H}), 4.67$ (t, $J=7 \mathrm{~Hz}, 1 \mathrm{H}), 7.24$ (d, $J=8$ $\mathrm{Hz}, 2 \mathrm{H}), 7.32$ (d, $J=8 \mathrm{~Hz}, 2 \mathrm{H}) ;{ }^{13} \mathrm{C} \mathrm{NMR}\left(\mathrm{CDCl}_{3}, 75 \mathrm{MHz}\right) \square 14.1,22.7,24.48$ and 24.53, 25.6, 26.35 and 26.38, 28.09 and 28.11, 28.7, 28.9, 30.4, 31.8, 33.9, 38.4, 39.0, 48.85 and 48.90, 55.68 and 55.80, 74.6, 126.4, 127.3, 142.42 and 142.43, 143.33 and $143.38,178.5,219.9$.

Epimerization of 21 to 24. A mixture of carboxylic acid 21 (50 mg, $0.099 \mathrm{mmol})$ and $\mathrm{LiOH} \cdot \mathrm{H}_{2} \mathrm{O}(21 \mathrm{mg}, 0.50 \mathrm{mmol})$ in $\mathrm{THF} / \mathrm{MeOH} / \mathrm{H}_{2} \mathrm{O}(1 \mathrm{~mL}, 3: 1: 1)$ was stirred vigorously for $1.5 \mathrm{~h}$ at room temperature, and diluted with saturated $\mathrm{NH}_{4} \mathrm{Cl}$. The aqueous layer was acidified to ( $\mathrm{pH} c a$. 5) by addition of phosphate buffer ( $\mathrm{pH}$ 3.6). The mixture was extracted with EtOAc four times and the combined layers were dried over $\mathrm{MgSO}_{4}$. After concentration under reduced pressure, the residue was purified by silica gel chromatography (hexane/EtOAc $=1: 1)$ to give $24(39 \mathrm{mg}, 78 \%):[\square]^{23}{ }_{\mathrm{D}}=-11.9(c$ 0.77, $\left.\mathrm{CHCl}_{3}\right)$; IR (neat) 3000, 1742, 1711, 1084, $836 \mathrm{~cm}^{-1} ;{ }^{1} \mathrm{H} \mathrm{NMR}\left(\mathrm{CDCl}_{3}, 300\right.$ $\mathrm{MHz}) \square-0.17$ (s, $3 \mathrm{H}), 0.00(\mathrm{~s}, 3 \mathrm{H}), 0.85$ (t, $J=7 \mathrm{~Hz}, 3 \mathrm{H}), 0.86$ (s, $9 \mathrm{H}), 1.00-1.75$ (m, $18 \mathrm{H}), 1.80-1.97$ (m, $1 \mathrm{H}), 2.13-2.34(\mathrm{~m}, 5 \mathrm{H}), 2.46-2.60(\mathrm{~m}, 1 \mathrm{H}), 2.94(\mathrm{dt}, J=11,6$ $\mathrm{Hz}, 1 \mathrm{H}), 4.60$ (dd, $J=7,5 \mathrm{~Hz}, 1 \mathrm{H}), 7.16(\mathrm{~d}, J=8 \mathrm{~Hz}, 2 \mathrm{H}), 7.24(\mathrm{~d}, J=8 \mathrm{~Hz}, 2 \mathrm{H})$; ${ }^{13} \mathrm{C} \mathrm{NMR}\left(\mathrm{CDCl}_{3}, 75 \mathrm{MHz}\right) \square-4.9,-4.5,14.1,18.3,22.7,24.6,25.4,25.9,26.6,28.06$ and $28.10,28.8,29.4,30.2,31.8,34.0,38.4,40.95$ and 40.98, 48.6, 56.07 and 56.11, $74.9,126.3,126.8,141.4,144.67$ and $144.69,220.00$ and 220.03. 


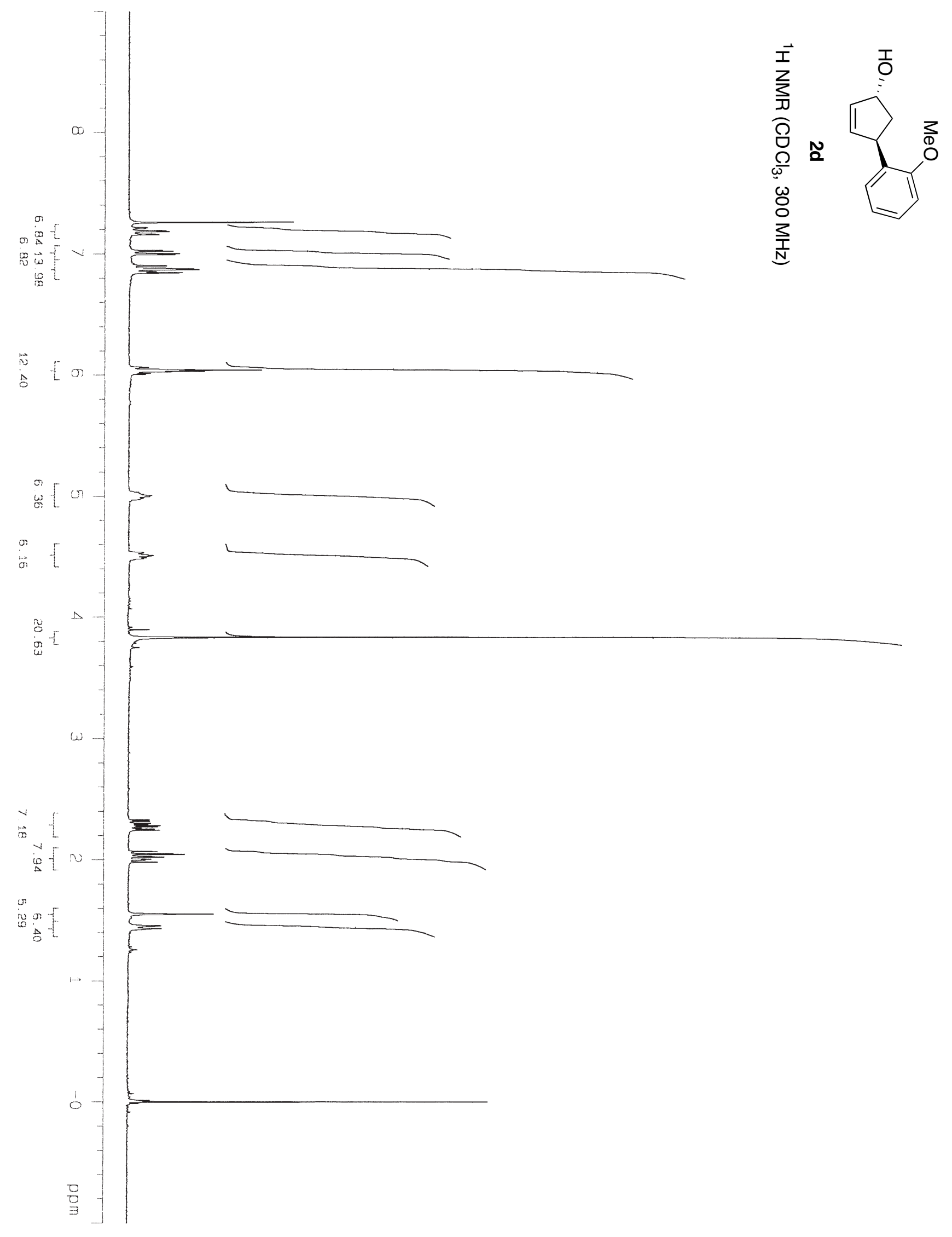




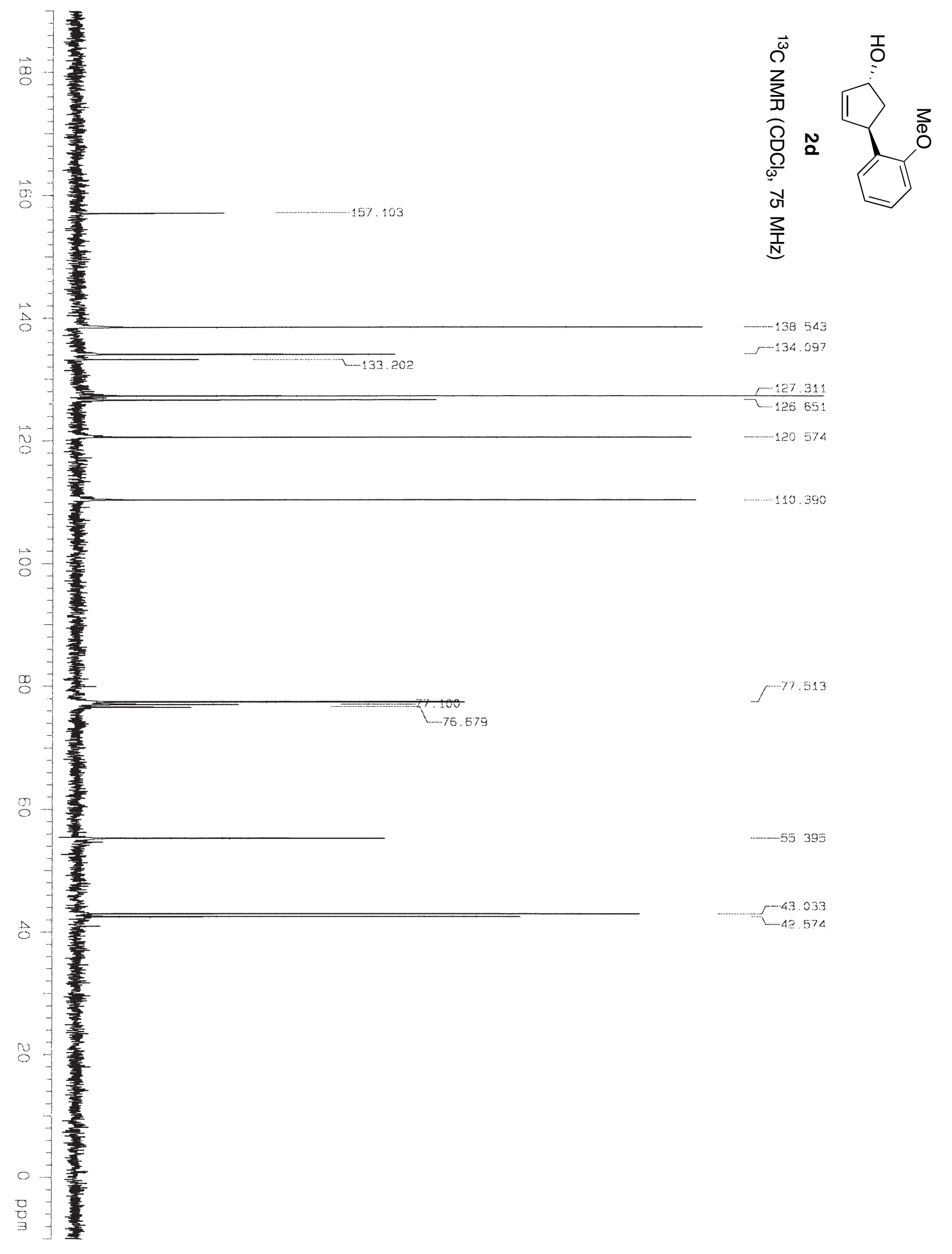




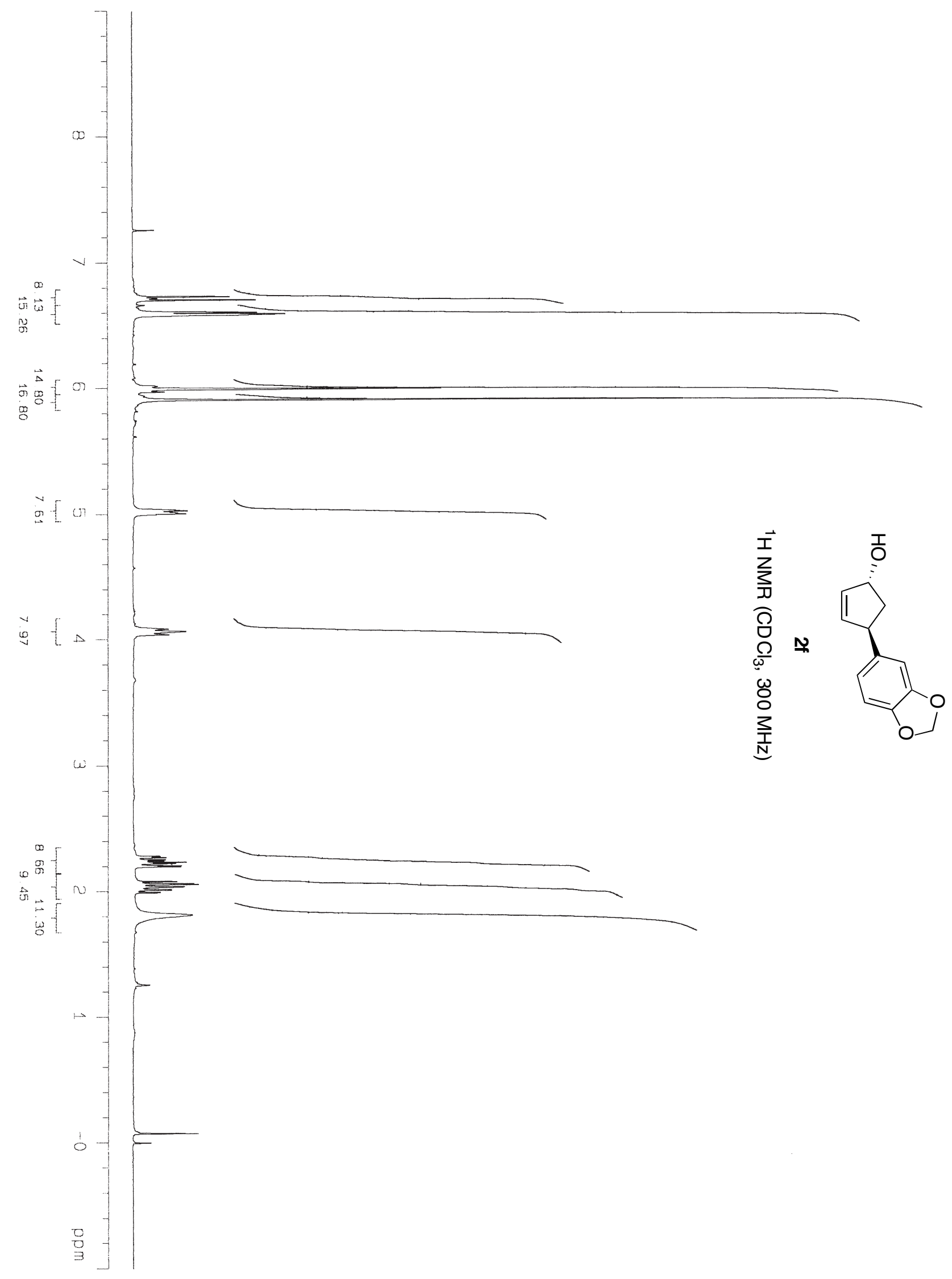




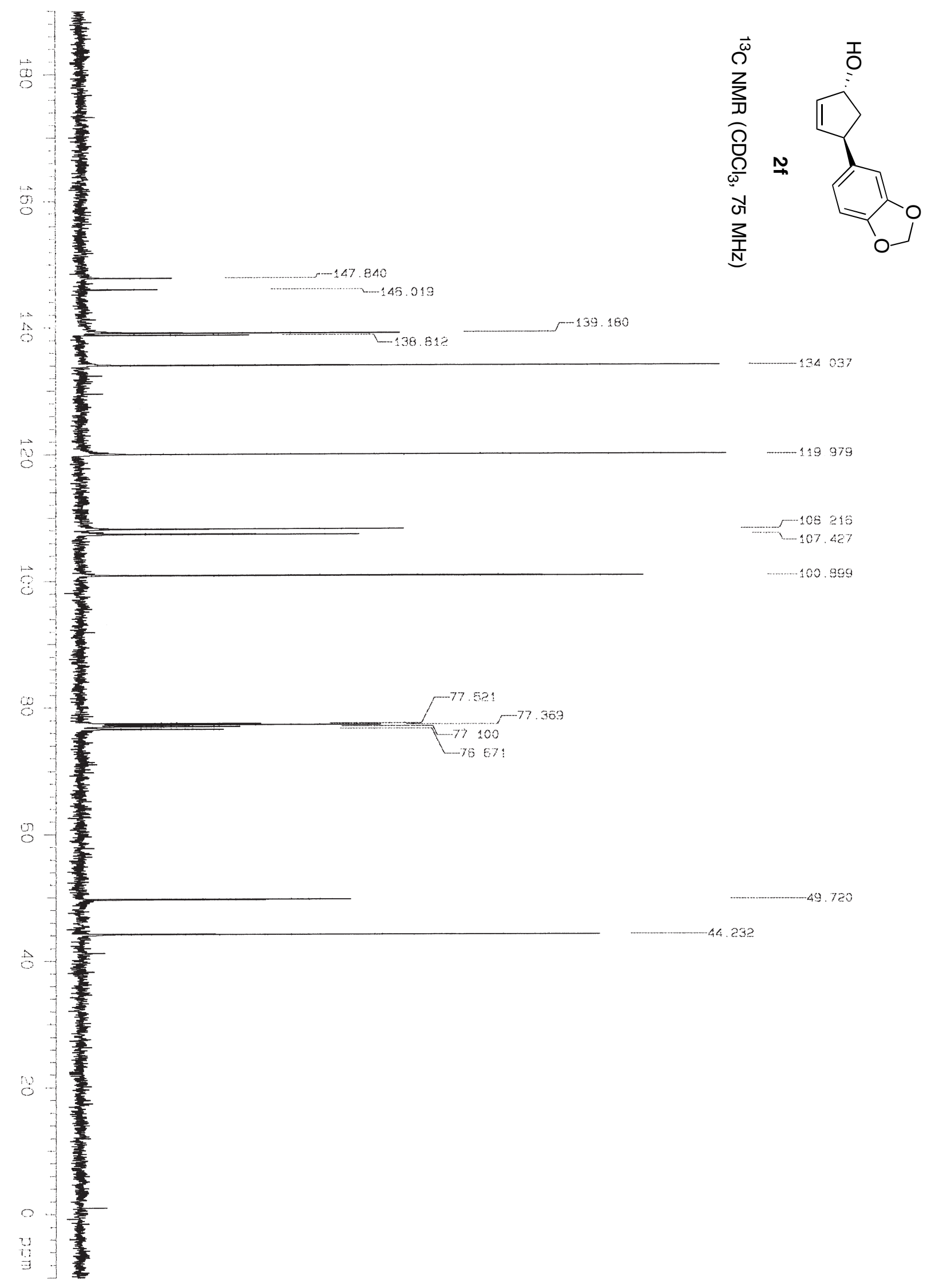




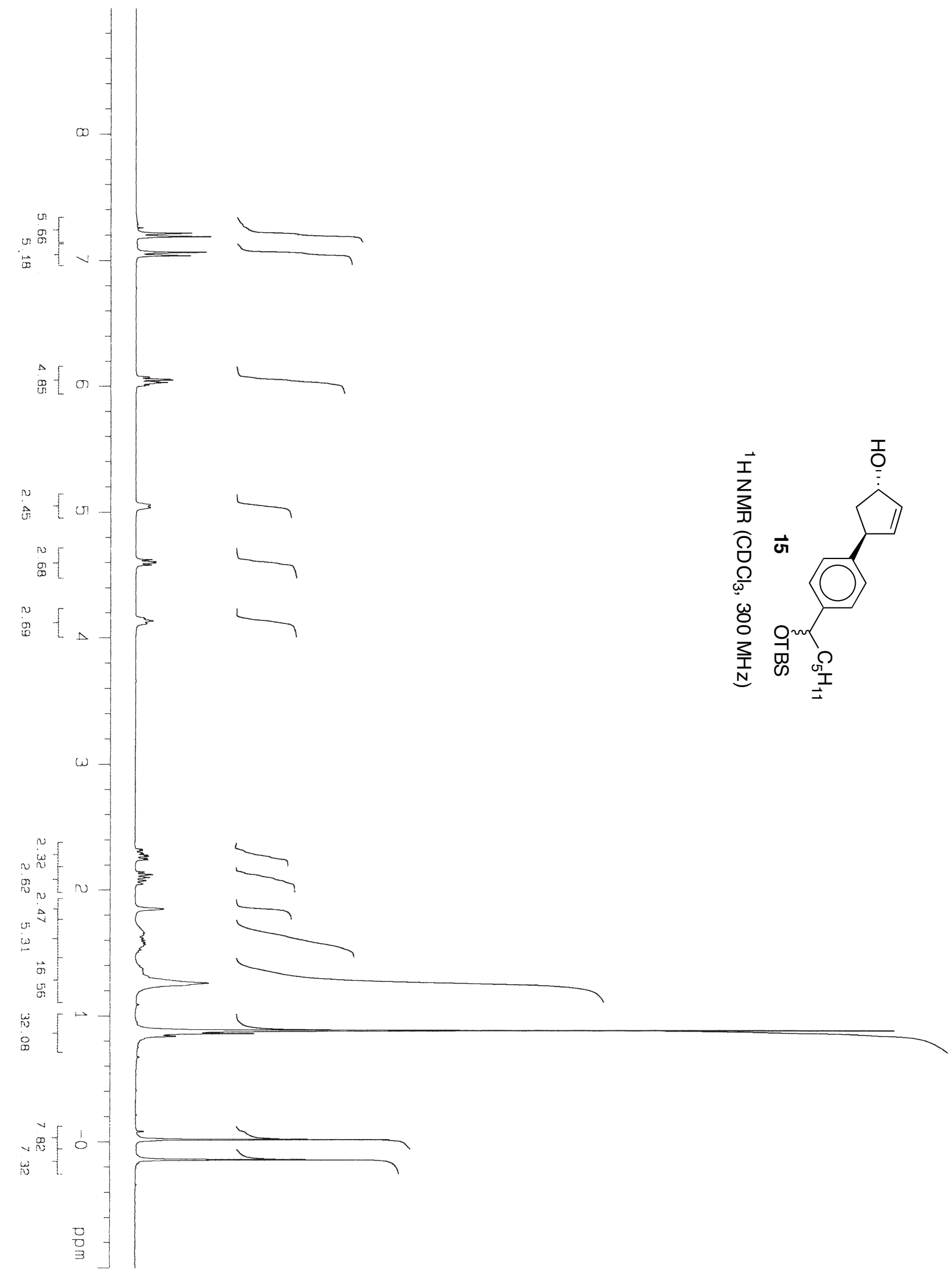




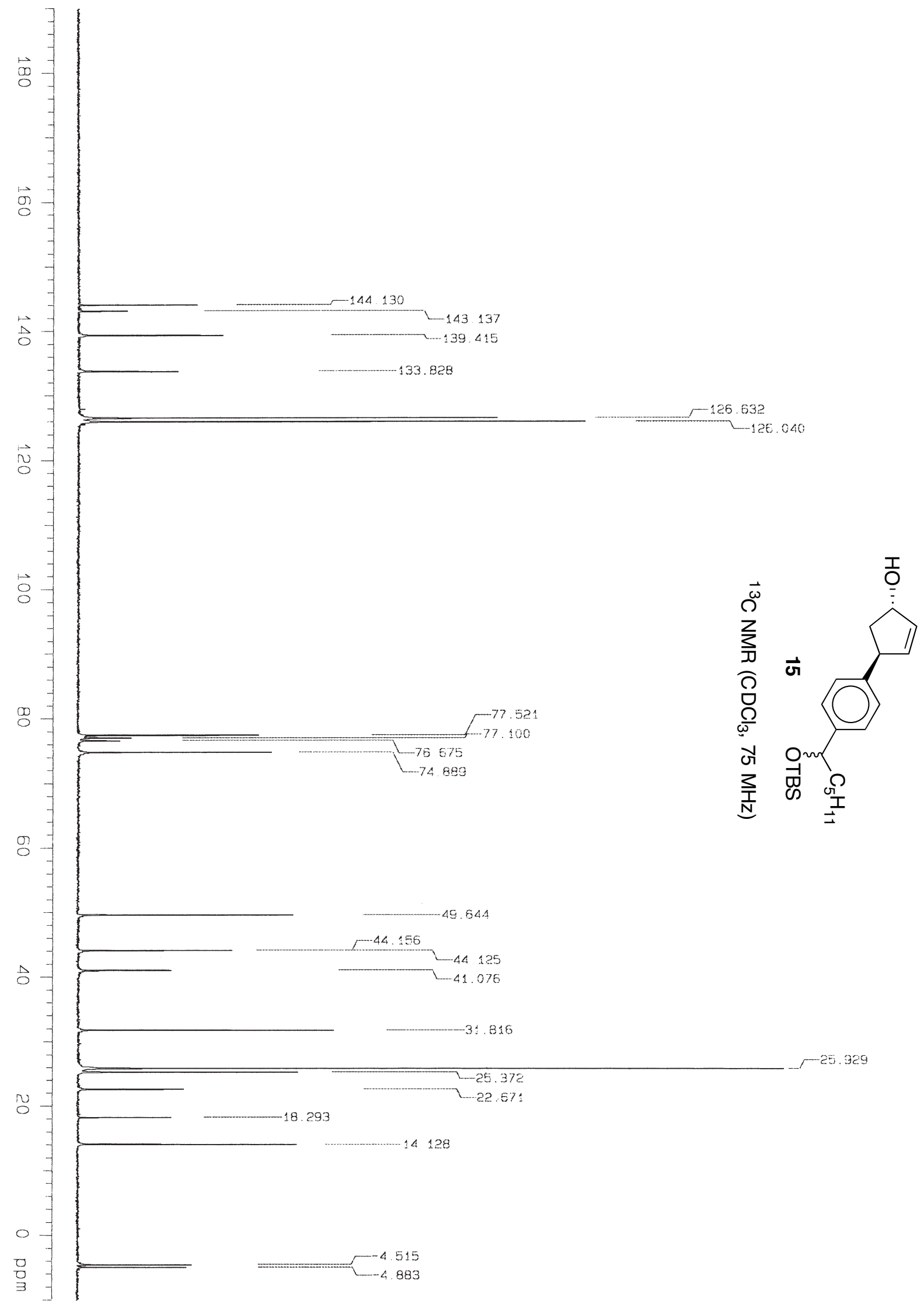




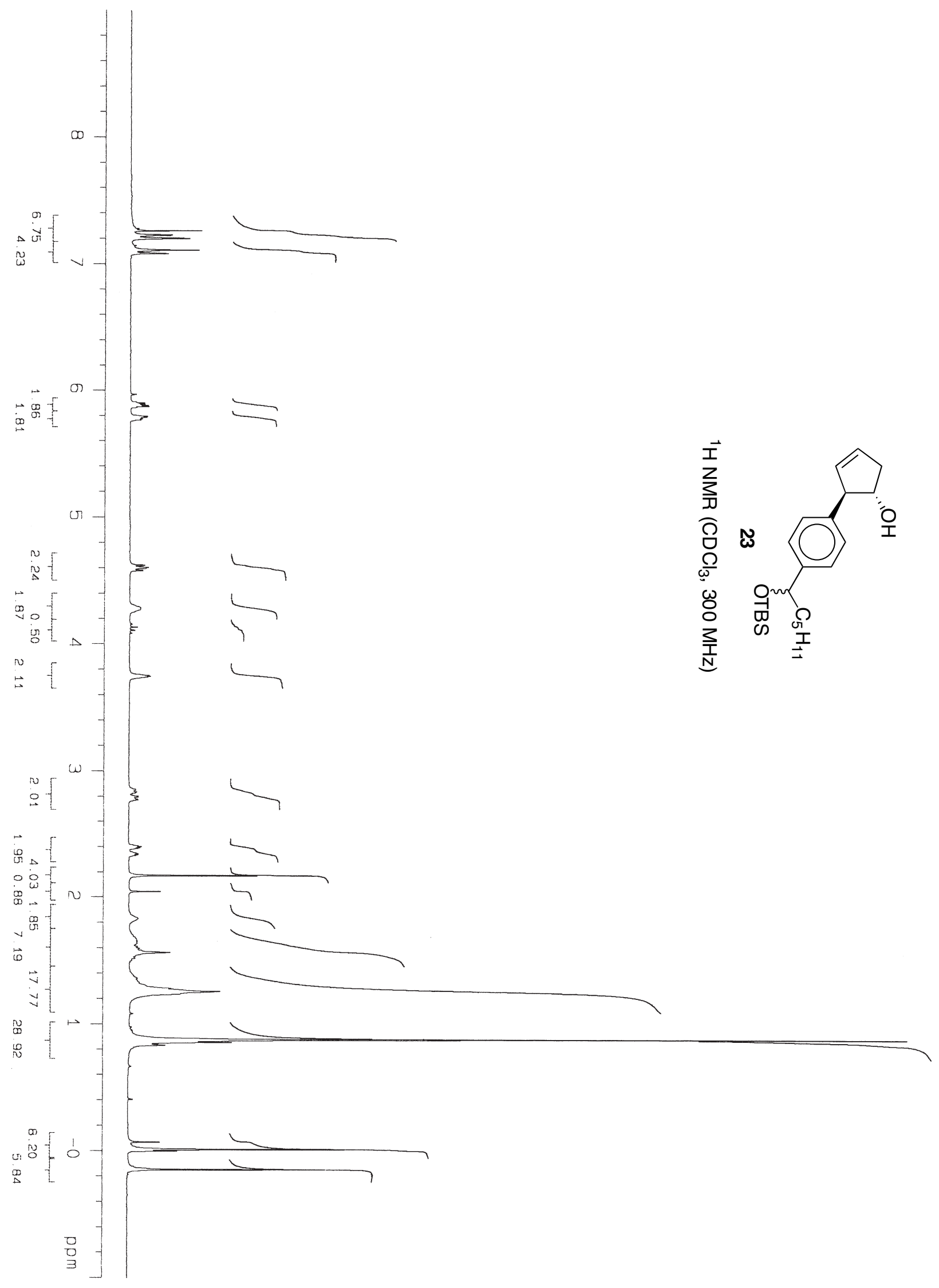




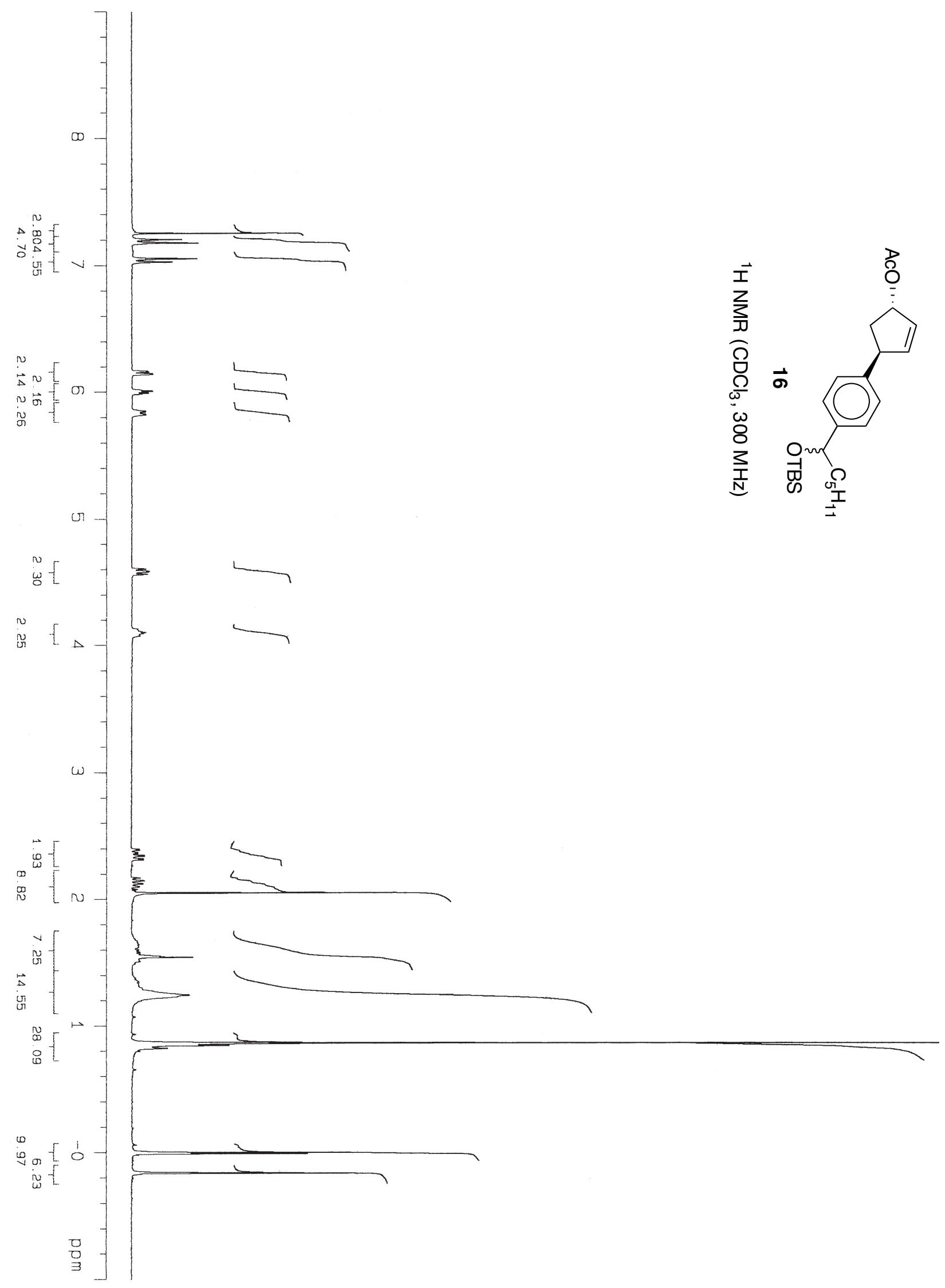




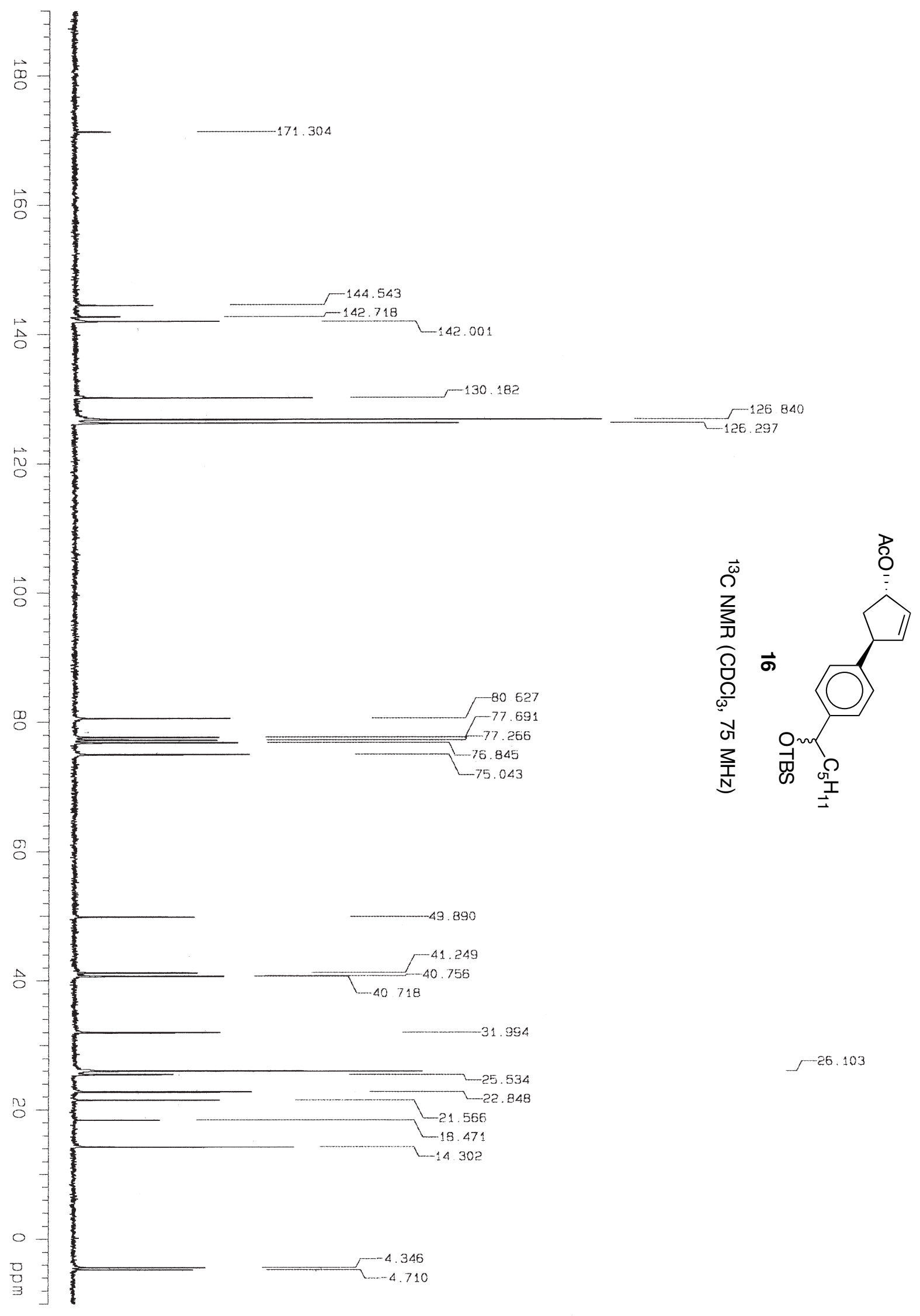




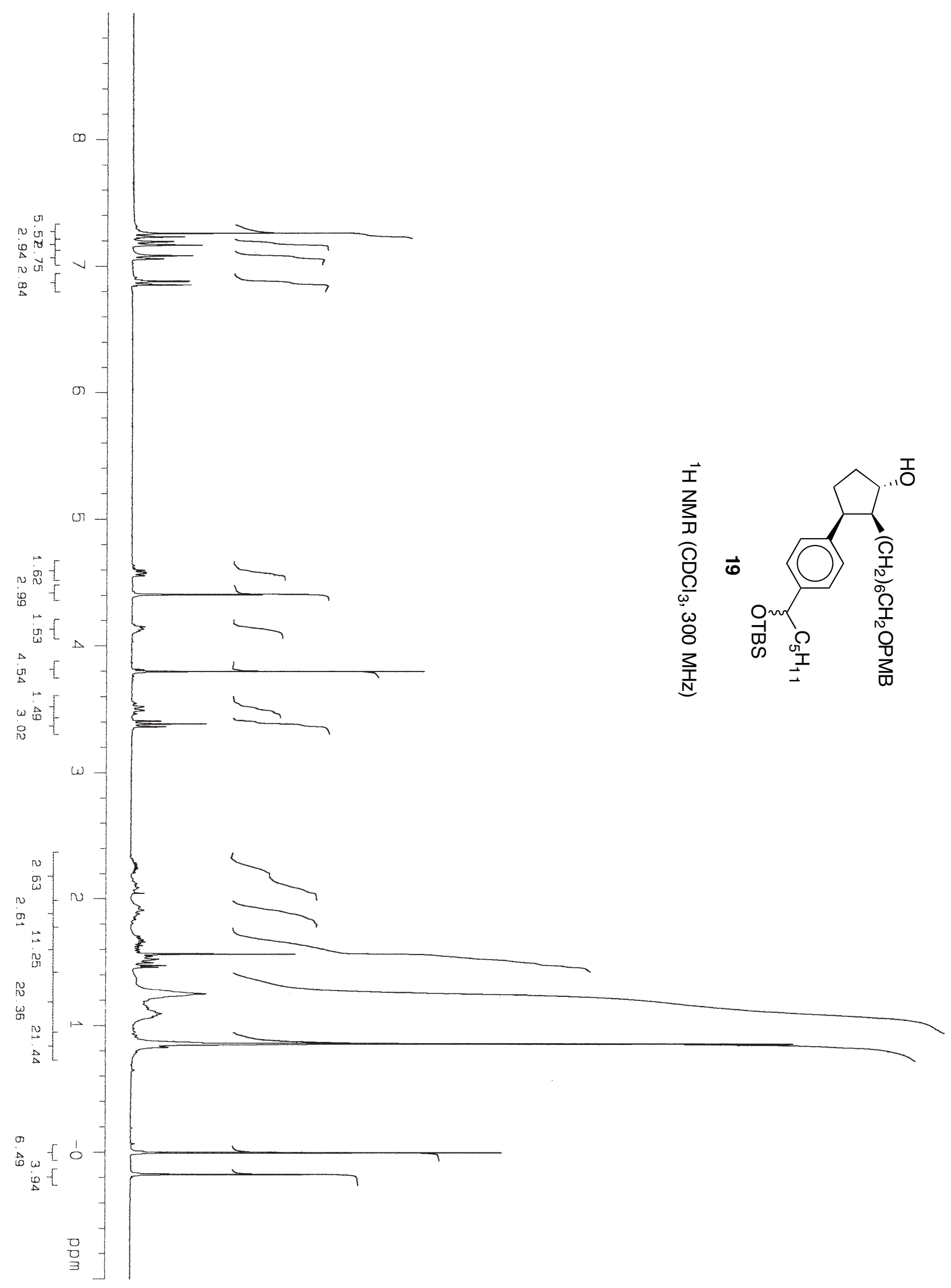




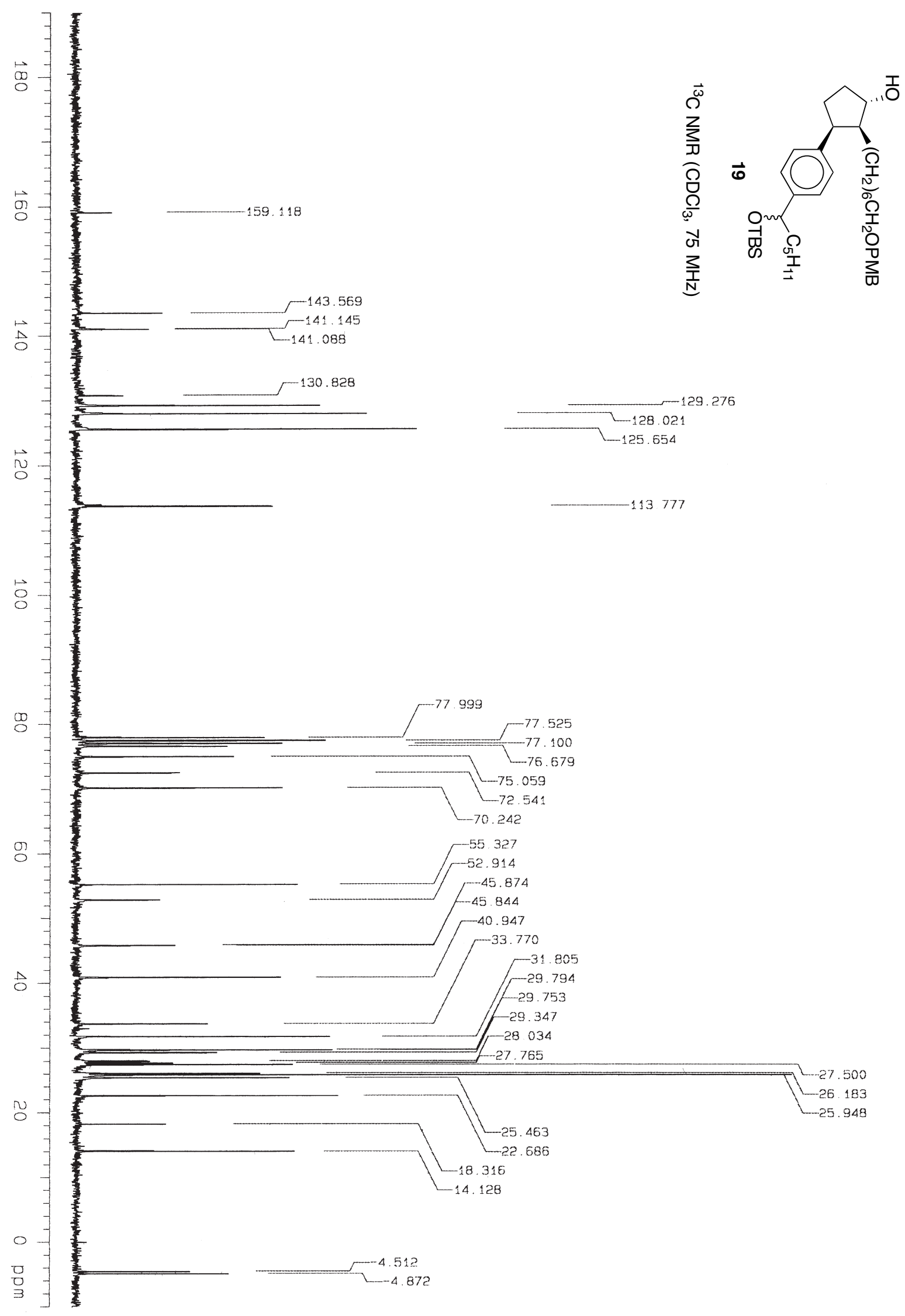




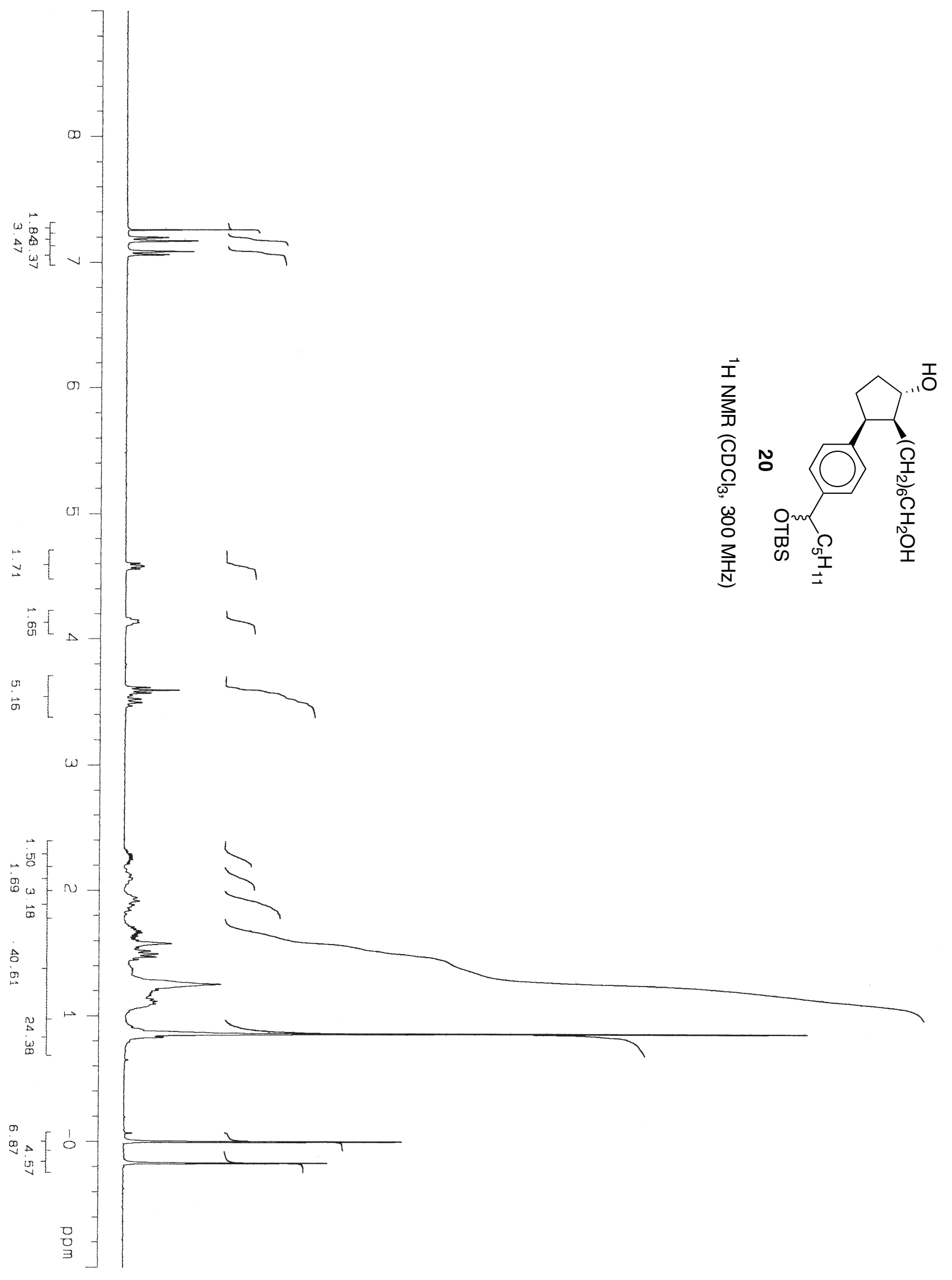




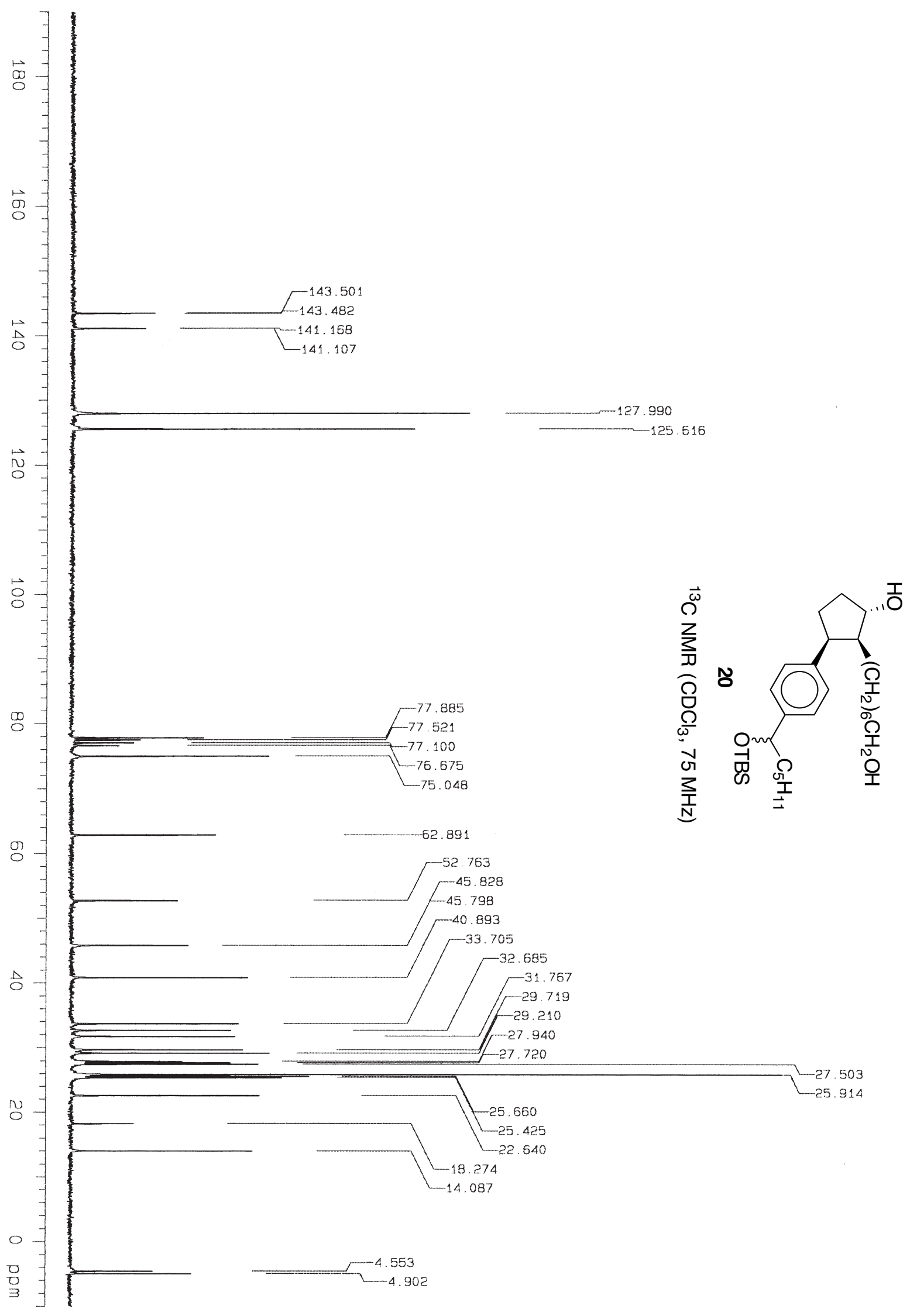




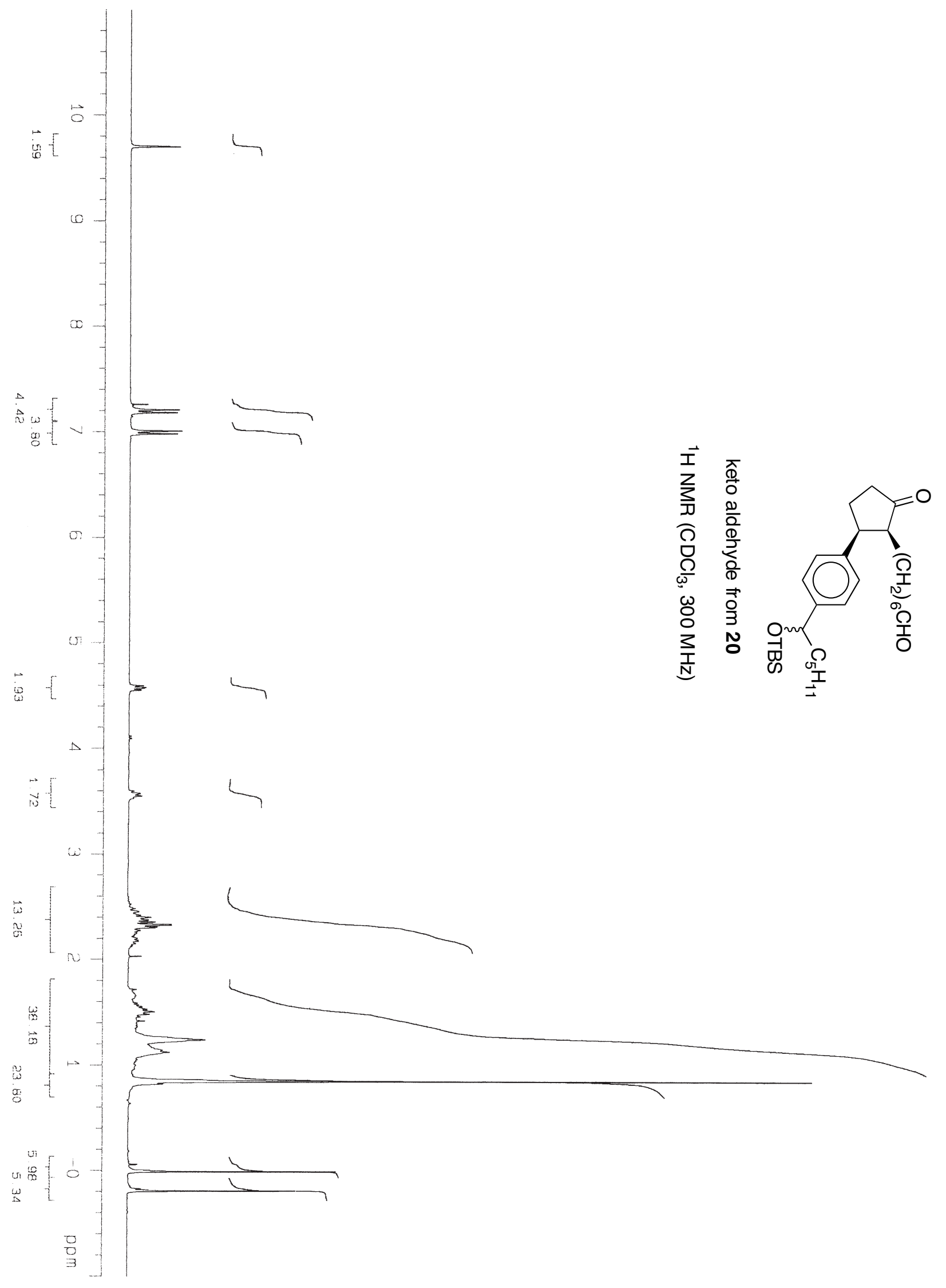




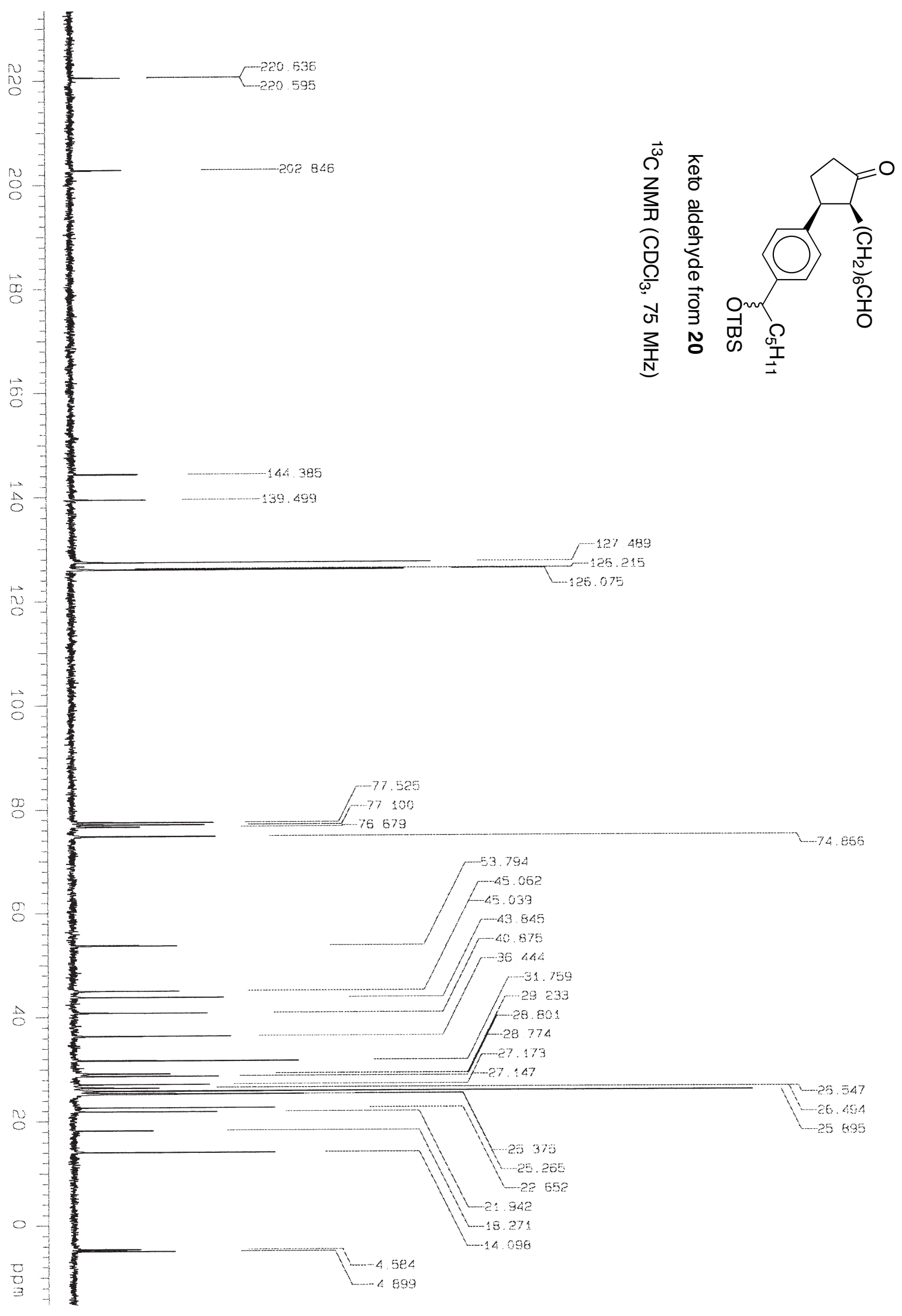




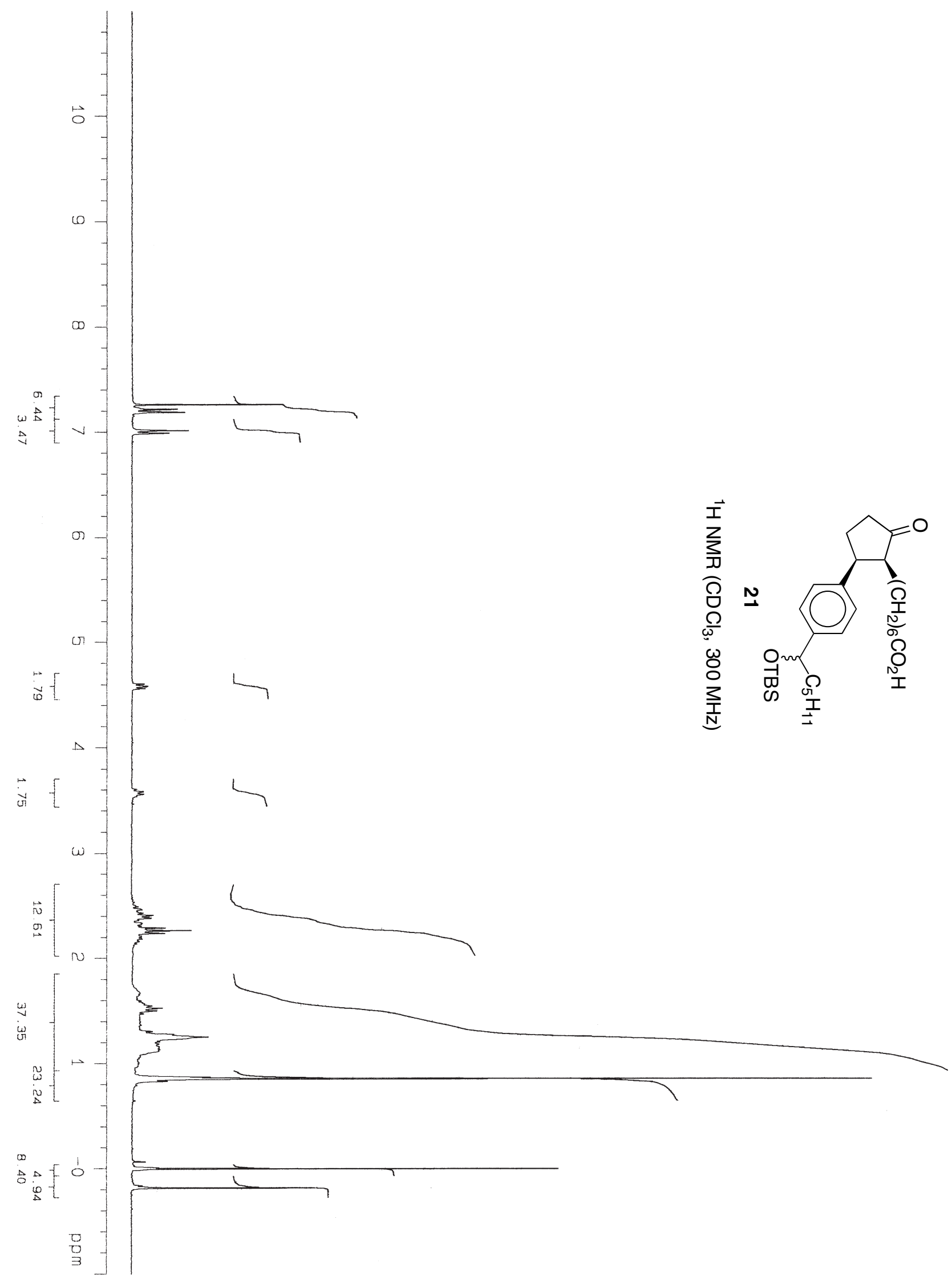




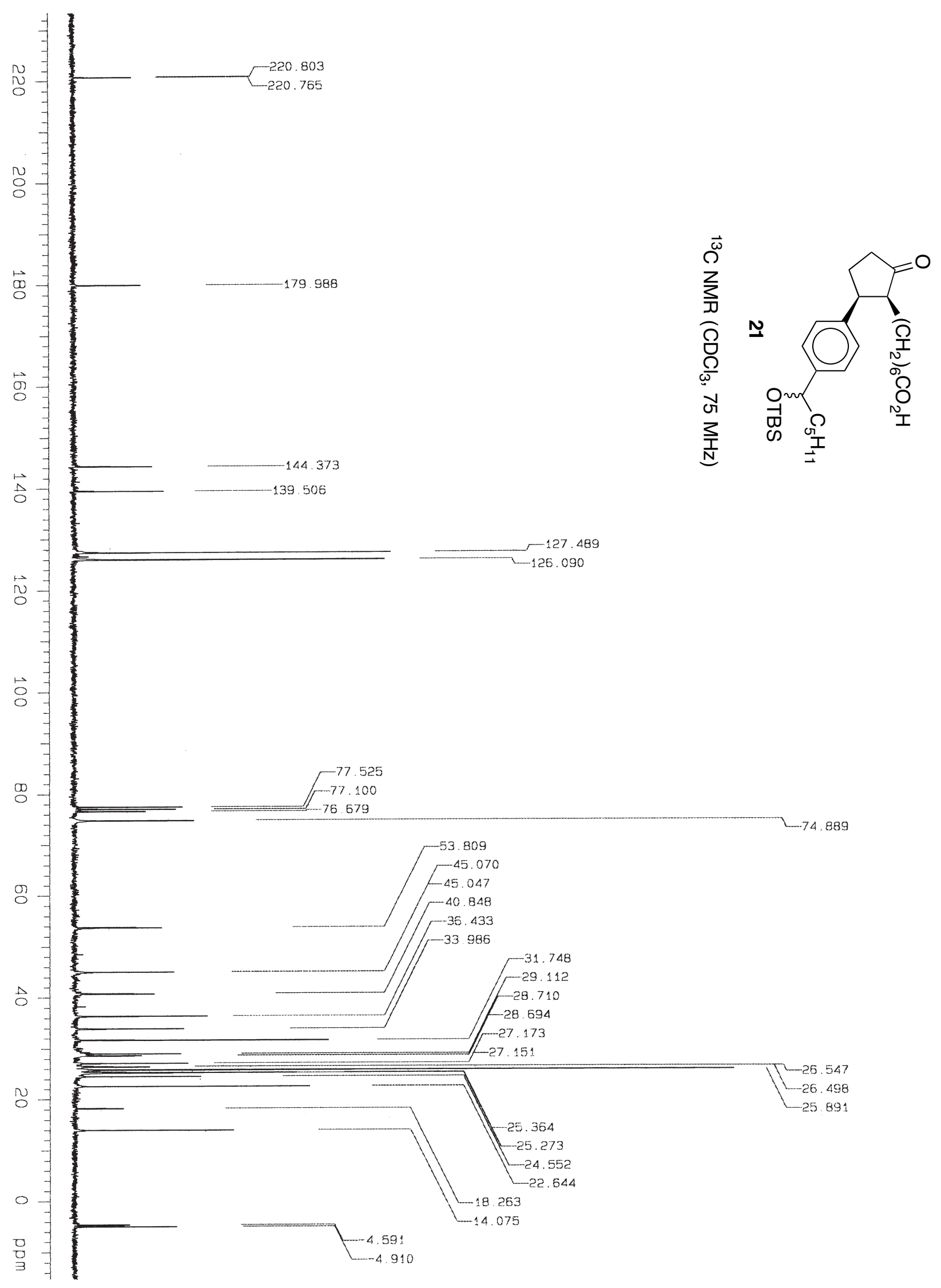




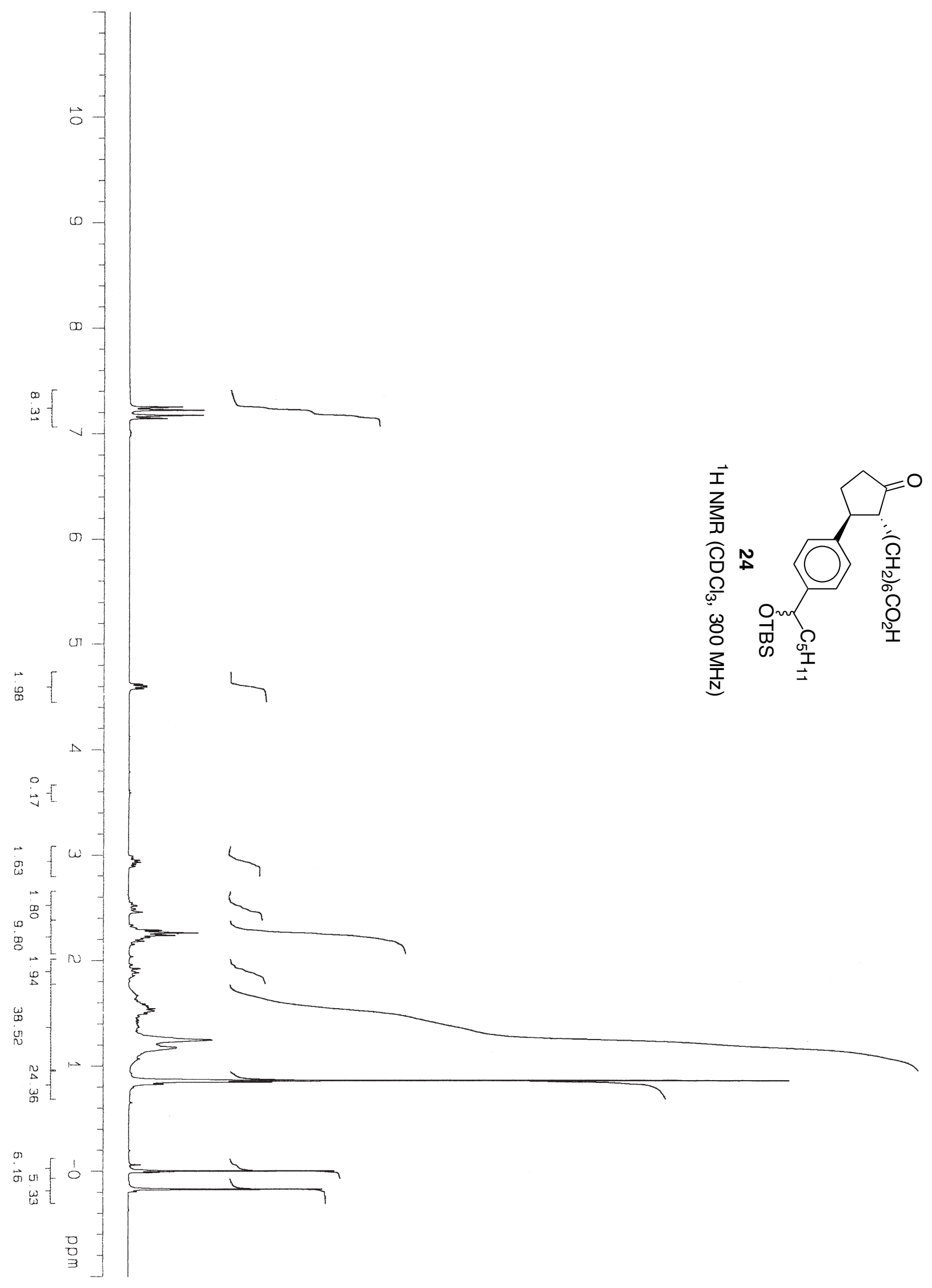




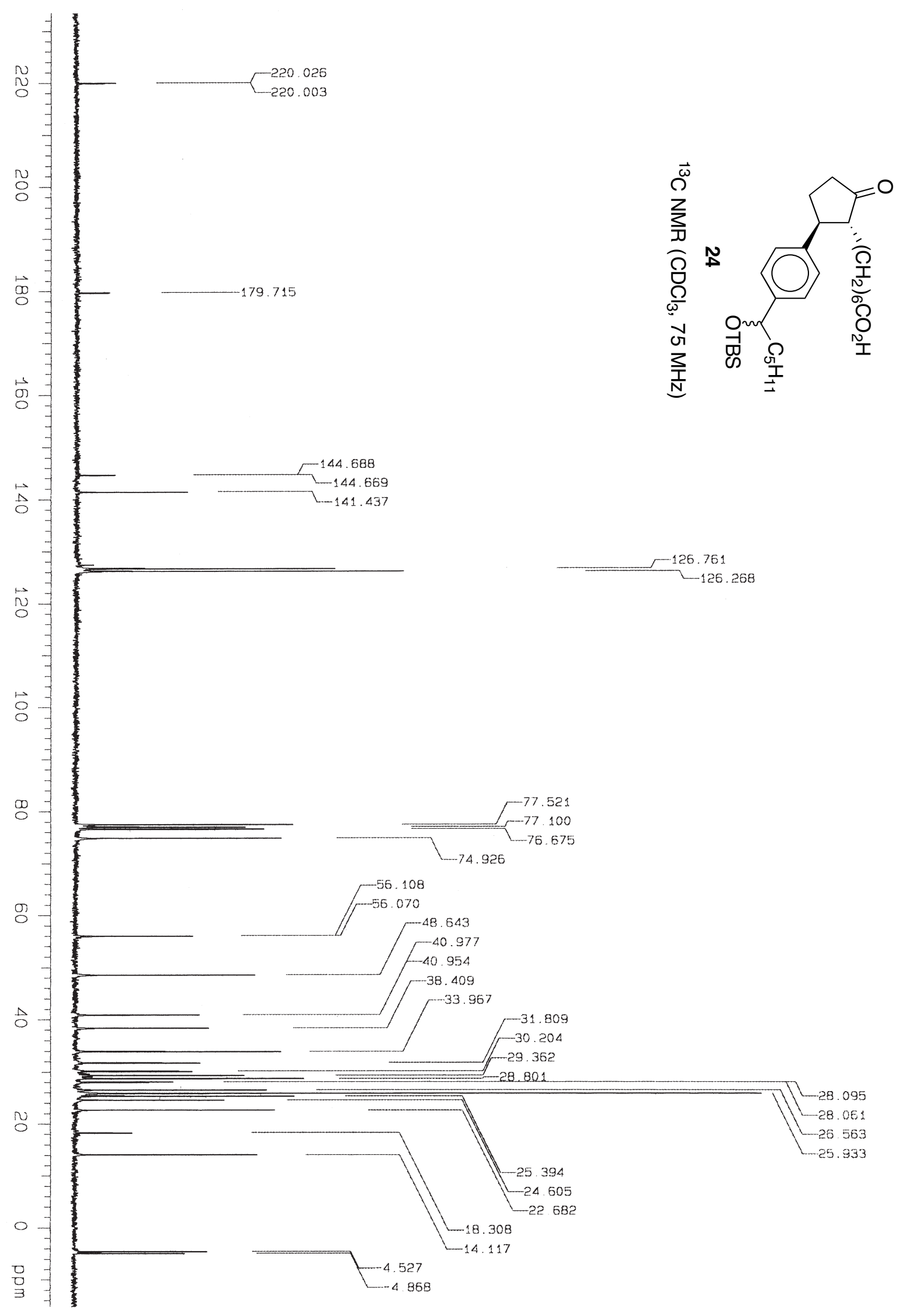




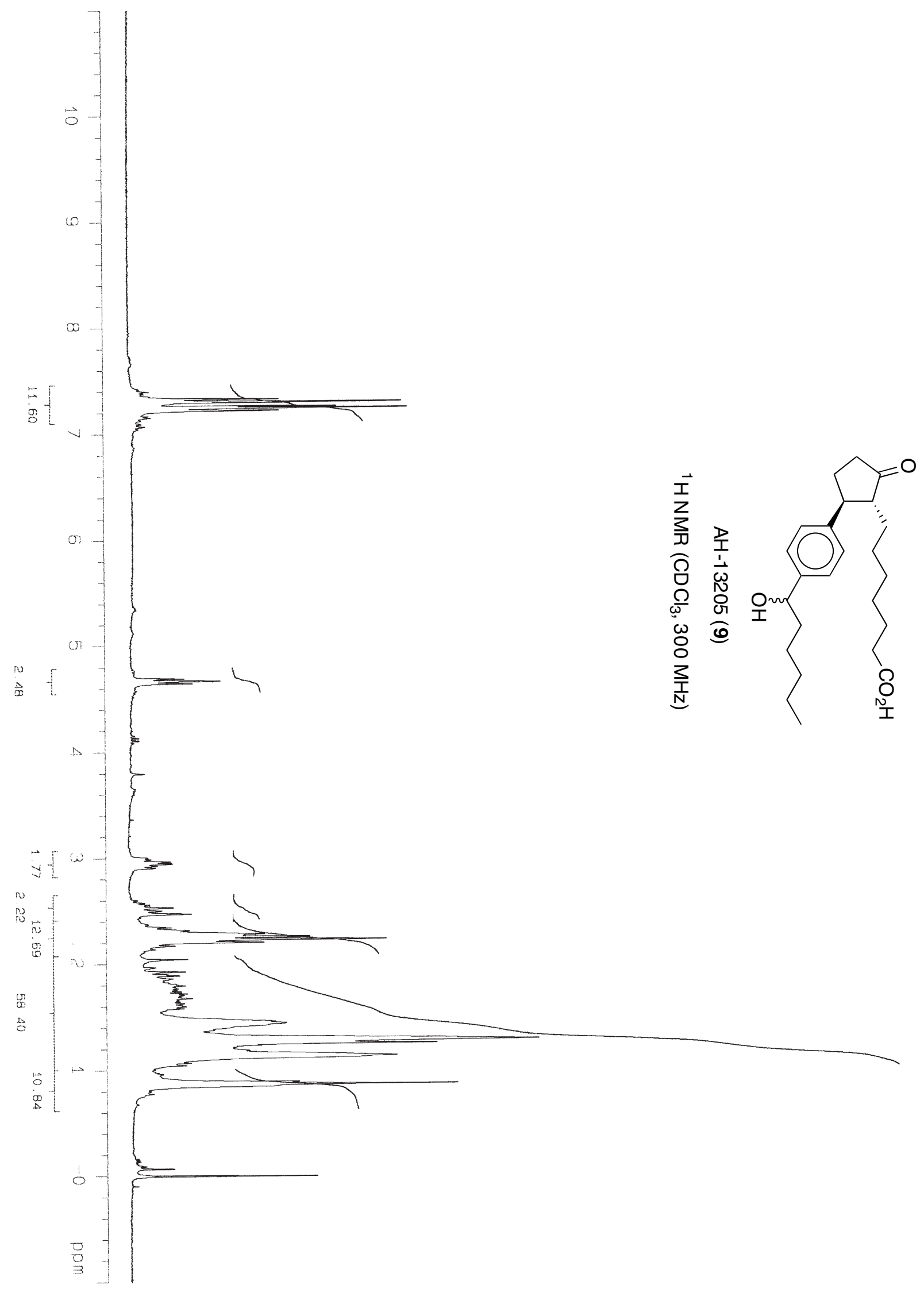




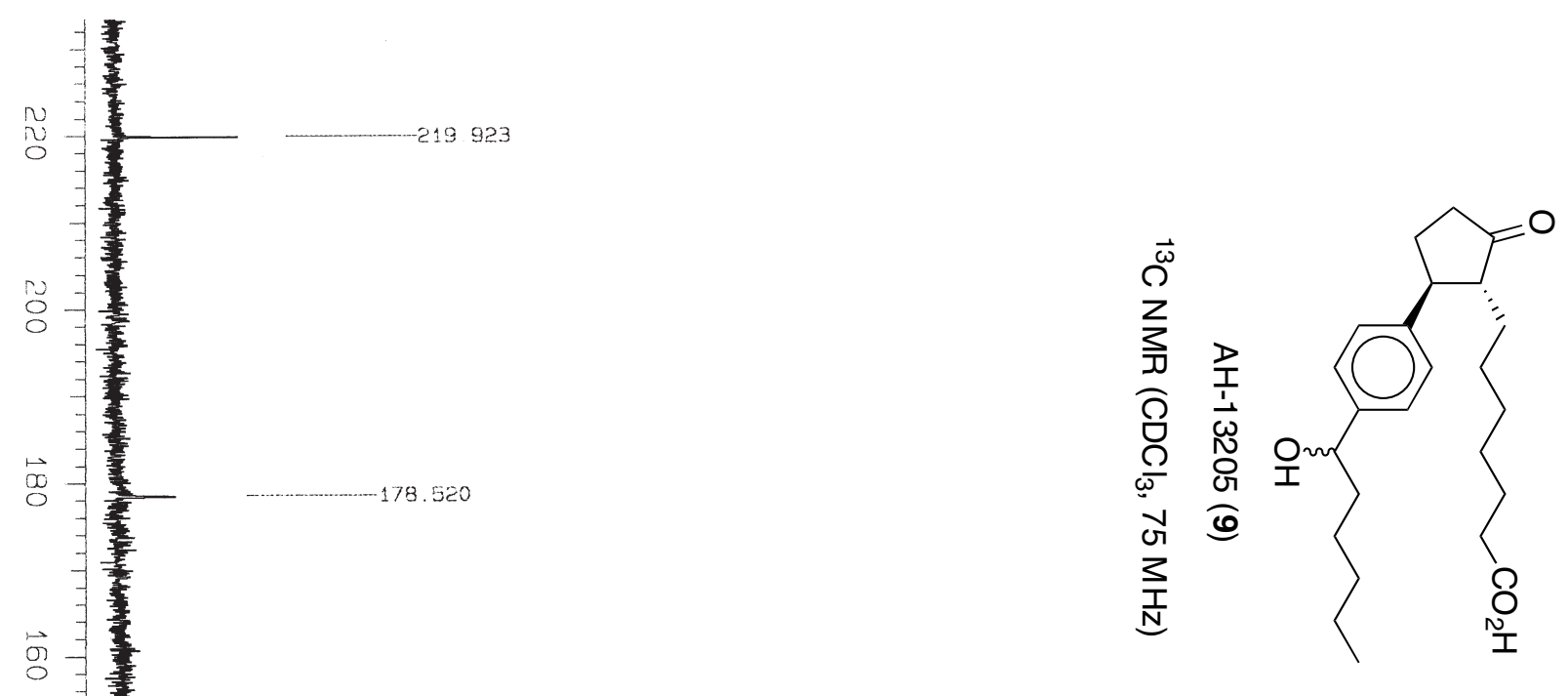

$\overrightarrow{0}$ $-143.38 \%$ $-143334$

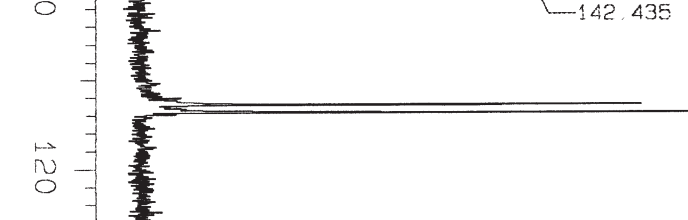

字

$\infty$
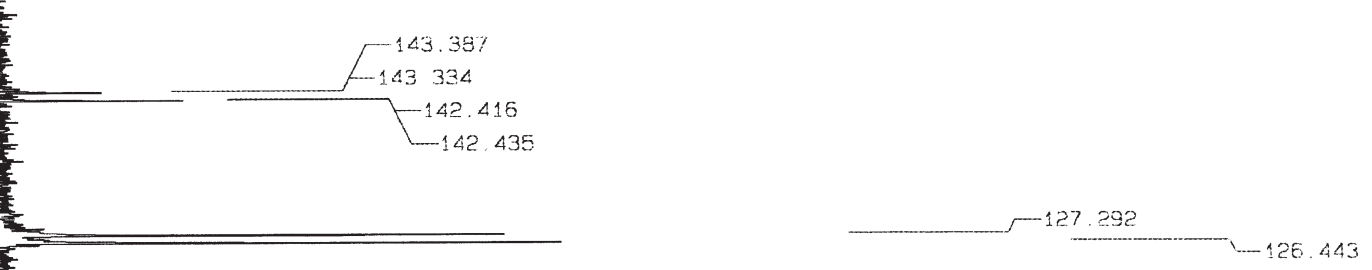

용

$\overrightarrow{0}$

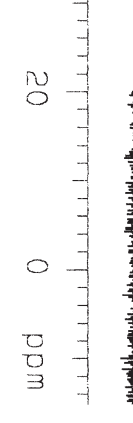

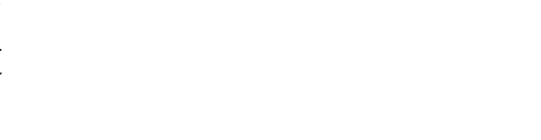

7.77525

77.309
-77.104

$\sqrt{-77.104}$
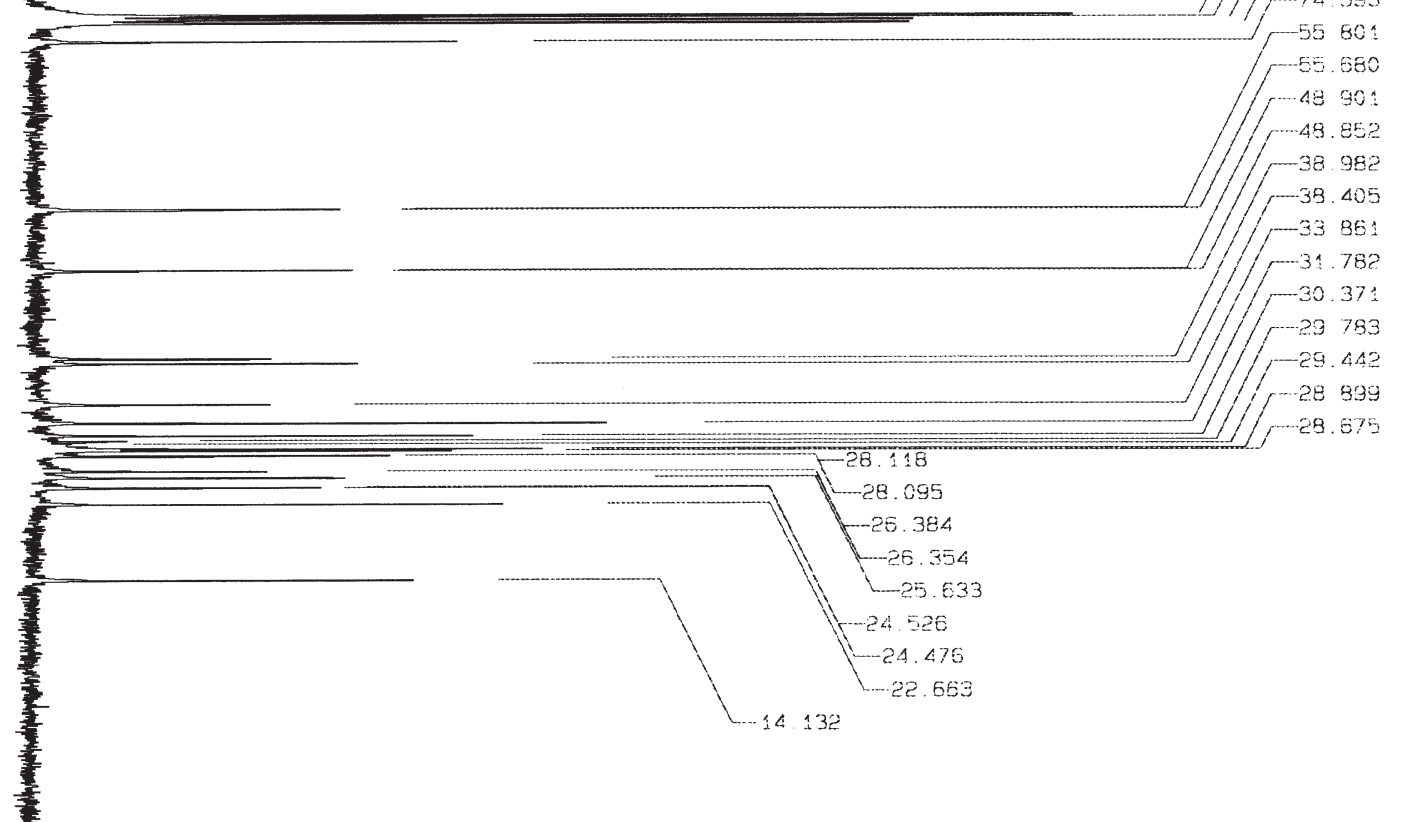